YJISHW
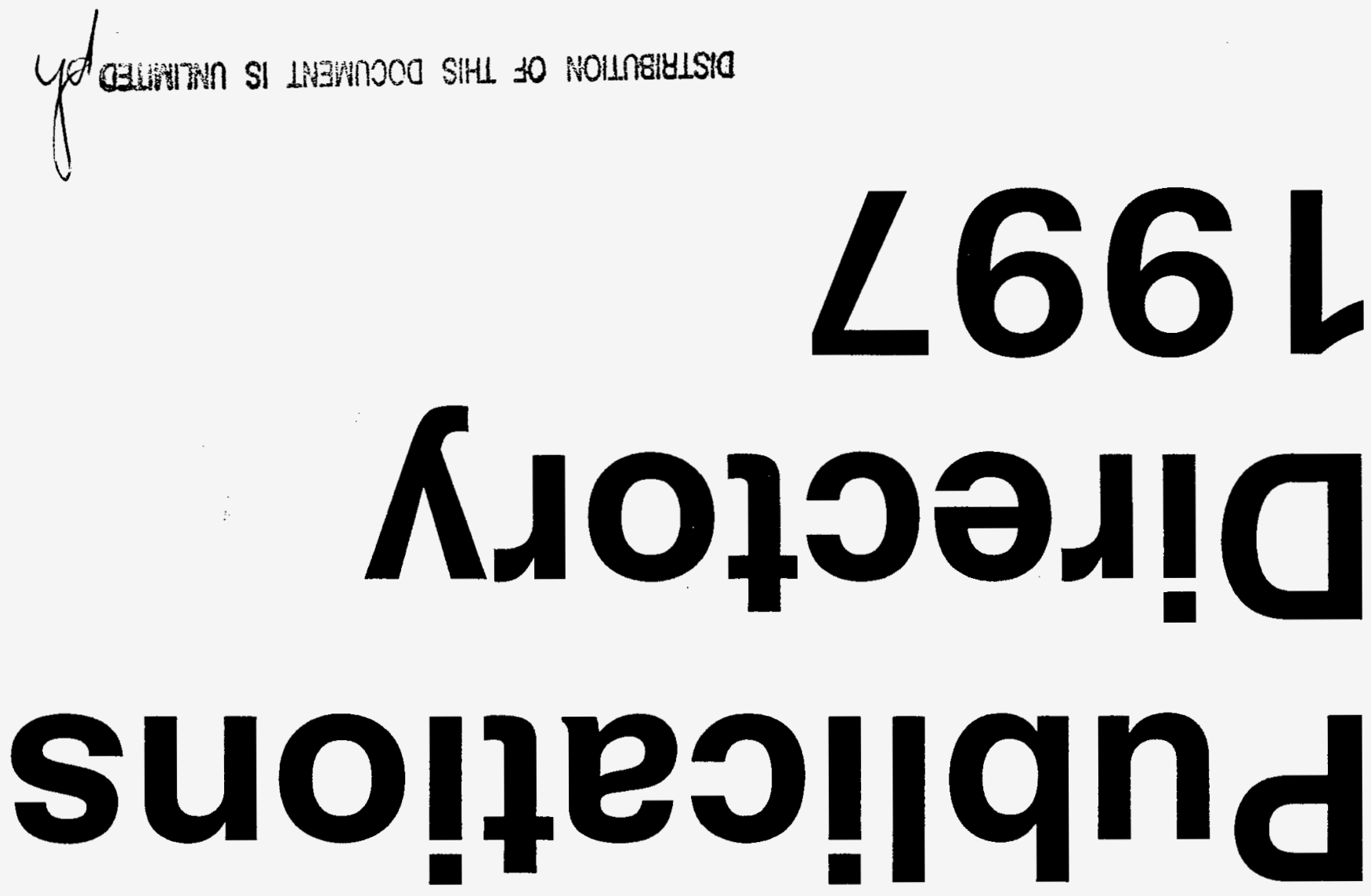

115

866,1 AVH

ozaldjat

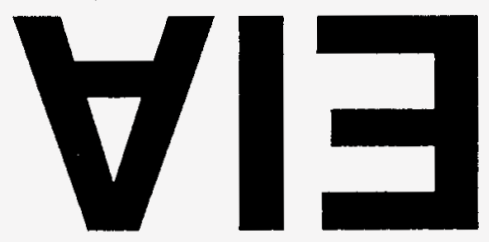




\section{HOW TO OBTAIN EIA PRODUCTS AND SERVICES}

For further information on any of the following services, or for answers to energy information questions, please contact EIA's National Energy Information Center:
National Energy Information Center (NEIC)
(202) 586-8800
Energy Information Administration
(202) 586-0727 (fax)
Forrestal Building, Room 1F-048, EI-30
TTY: (202) 586-1181
Washington, DC 20585
E-mail: infoctr@eia.doe.gov

\section{Electronic Products and Services}

EIA's Internet Site Services offer nearly all EIA publications. Users can view and download selected pages or entire reports, search for information, download EIA data and analysis applications, and find out about new EIA information products and services.

\section{World Wide Web: http://www.eia.doe.gov \\ Gopher: gopher://gopher.eia.doe.gov \\ FTP: ftp://ftp.eia.doe.gov}

EIA also offers a listserve service for EIA press releases and other short documents. Sign up on the EIA World Wide Web site.

EIA's CD-ROM, Energy InfoDisc, contains most EIA publications, several databases, and an energy forecasting model. The Energy InfoDisc, produced quarterly, is available for a fee from STAT-USA, Department of Commerce, 1-800-STAT-USA.

The Comprehensive Oil and Gas Information Source (COGIS), a bulletin board service, contains data files from most of EIA's oil-and gas-related reports. It is available for a fee from STAT-USA, on 1-800-STAT-USA.

EIA's Electronic Publishing System (EPUB) bulletin board contains data files, directories, and forecasts from most EIA reports. It can be accessed free of charge by dialing (202) 586-2557.

Many of EIA's data files and modeling programs are available for sale on diskette, tape, or cartridge, through either the National Technical Information Service or the Office of Scientific and Technical Information, Department of Energy. Contact NEIC for information on specific products, sources, and media, and ordering instructions.

\section{Printed Publications}

EIA directories are available free of charge from NEIC. Recent periodicals and one-time reports are available from the Government Printing Office. Older reports are available from the National Technical Information Service:

Superintendent of Documents

U.S. Government Printing Office

P.O. Box 371954

Pittsburgh, PA 15250-7954

(202) 512-1800; (202)-512-2250 (fax)
National Technical Information Service

U.S. Department of Commerce

Springfield, VA 22161

5285 Port Royal Road

1-800-553-6847 or (703) 605-6000;

(703) $321-8547$ (fax) 
DOE/EIA-0149(97)

Distribution Category UC-950

\title{
EIA Publications Directory 1997
}

\author{
April 1998
}

Energy Information Administration

National Energy Information Center

U.S. Department of Energy

Washington, DC 20585

This report was prepared by the Energy Information Administration, the independent statistical and analytical agency within the Department of Energy. The information contained herein should not be construed as advocating or reflecting any policy position of the Department of Energy or any other organization. 


\section{DISCLAIMER}

This report was prepared as an account of work sponsored by an agency of the United States Government. Neither the United States Government nor any agency thereof, nor any of their employees, makes any warranty, express or implied, or assumes any legal liability or responsibility for the accuracy, completeness, or usefulness of any information, apparatus, product, or process disclosed, or represents that its use would not infringe privately owned rights. Reference herein to any specific commercial product, process, or service by trade name, trademark, manufacturer, or otherwise does not necessarily constitute or imply its endorsement, recommendation, or favoring by the United States Government or any agency thereof. The views and opinions of authors expressed herein do not necessarily state or reflect those of the United States Government or any agency thereof. 


\section{Preface}

Enacted in 1977, the Department of Energy (DOE) Organization Act established the Energy Information Administration (EIA) as the Department's independent statistical and analytical agency, with a mandate to collect and publish data and prepare analyses on energy production, consumption, prices, resources, and projections of energy supply and demand. This edition of the EIA Publications Directory contains titles and abstracts of periodicals and one-time reports produced by EIA from January through December 1997.
The body of the Directory contains citations and abstracts arranged by broad subject categories; metadata, coal, oil and gas, nuclear, electricity, renewable and energy/alternative fuels, multifuel, end-use consumption, models, and forecasts.

Questions concerning publications in the Directory should be directed to the National Energy Information Center (NEIC) at (202) 5868800.

Comments on the Directory itself should be directed to Karen Freedman at (202) 586-9254. 


\section{How to Use the EIA Publications Directory}

Availability. This directory contains abstracts and brief ordering information for individual issues of semiannual, annual, biennial, and triennial periodicals, analysis reports, Service Reports, and model documentation. (Service Reports are prepared by EIA upon special request and may be based on assumptions specified by the requestor.) Most publications are available from the National Technical Information Service (NTIS), U.S. Department of Commerce. Contact NTIS at (703) 605-6000 for all specific ordering information.

Periodicals produced more frequently than semiannually -- quarterlies, monthlies, and weeklies -- are listed as single titles. Individual issues are not listed, and no ordering information is given. If the periodical is current, it is available by subscription from the U.S. Government Printing Office (GPO). Contact GPO at (202) 512-1800.

Some recent individual issues are also available from GPO. Most recent issues of current and discontinued periodicals are available from NTIS. For ordering information regarding these periodicals, call NTIS directly. Annual and one-time reports which are available from GPO are indicated with a GPO stock number and price.

Abstracts. Publication abstracts are arranged by abstract number within subject categories as listed in the table of contents.

Subject Index. The subject index is arranged alphabetically by specific energy terminology. The numbers that follow each entry refer the reader to the related publication abstract. 


\section{Contents}

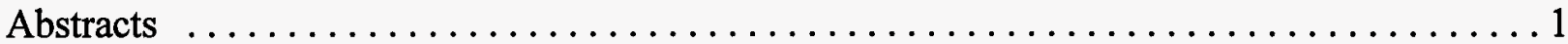

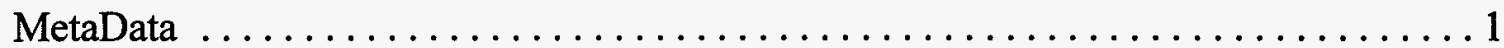

Annual Report to Congress $1996 \ldots \ldots \ldots \ldots \ldots \ldots \ldots \ldots \ldots \ldots$

EIA Information Directory $1996 \ldots \ldots \ldots \ldots \ldots \ldots \ldots \ldots \ldots \ldots$

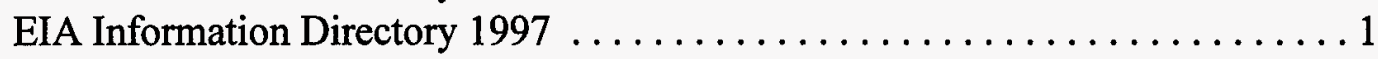

EIA New Releases . . . . . . . . . . . . . . . . . . . . . . 1

EIA Publications Directory $1996 \ldots \ldots \ldots \ldots \ldots \ldots \ldots \ldots \ldots \ldots \ldots$

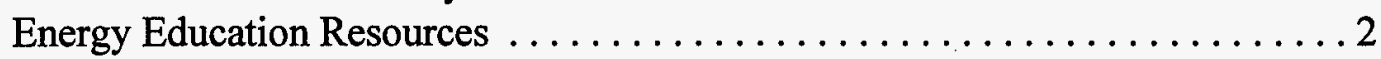

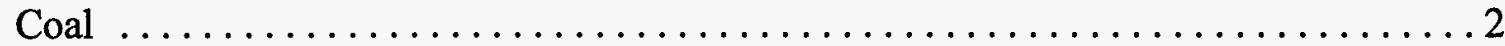

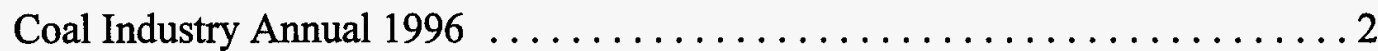

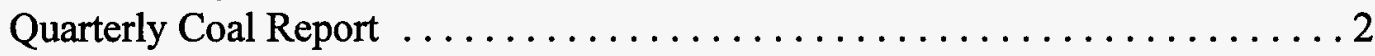

Oil and Natural Gas . . . . . . . . . . . . . . . . . . . . . . . . . 2

An Analysis of U.S. Propane Markets Winter 1996-97 . . . . . . . . . . . . 2

Fuel Oil and Kerosene Sales $1996 \ldots \ldots \ldots \ldots \ldots \ldots \ldots \ldots \ldots$

International Petroleum Statistics Report $\ldots \ldots \ldots \ldots \ldots \ldots \ldots \ldots$

Motor Gasoline Assessment, Spring $1997 \ldots \ldots \ldots \ldots \ldots \ldots \ldots \ldots$

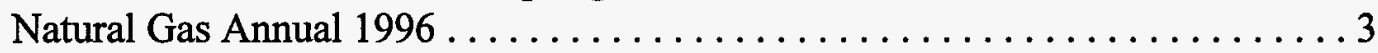

Natural Gas Monthly . . . . . . . . . . . . . . . . . . . . . 4

Oil and Gas Resources of the West Siberian Basin, Russia . . . . . . . . . . 4

Petroleum Marketing Monthly . . . . . . . . . . . . . . . . . . 4

Petroleum Supply Annual 1996, Volume $1 \ldots \ldots \ldots \ldots \ldots \ldots \ldots \ldots \ldots$

Petroleum Supply Annual 1996, Volume $2 \ldots \ldots \ldots \ldots \ldots \ldots \ldots \ldots$

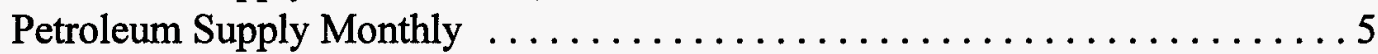

Petroleum 1996: Issues and Trends . . . . . . . . . . . . . . . . 6

U.S. Crude Oil, Natural Gas, and Natural Gas Liquids Reserves

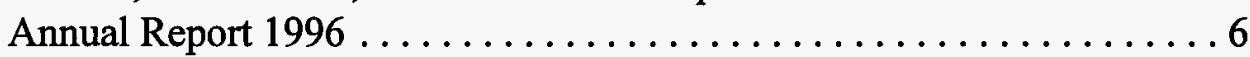

Weekly Petroleum Status Report . . . . . . . . . . . . . . . . . 6

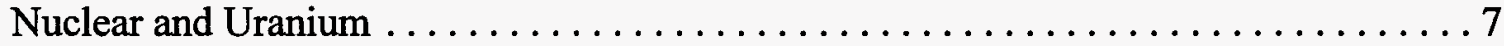

Nuclear Power Generation and Fuel Cycle Report 1997 . . . . . . . . . . . . . 7

Uranium Industry Annual $1996 \ldots \ldots \ldots \ldots \ldots \ldots \ldots \ldots \ldots$

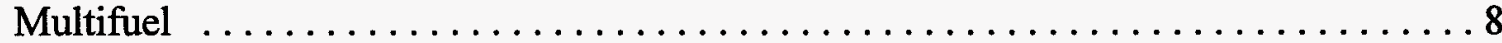

Annual Energy Review $1996 \ldots \ldots \ldots \ldots \ldots \ldots \ldots \ldots \ldots \ldots \ldots$

Emissions of Greenhouse Gases in the United States $1996 \ldots \ldots \ldots \ldots \ldots$. . . 8

Mitigating Greenhouse Gas Emissions: Voluntary Reporting . . . . . . . . 8

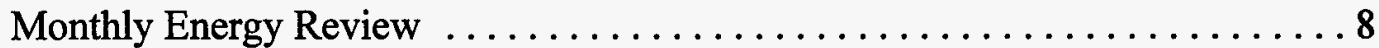

Performance Profiles of Major Energy Producers 1995 . . . . . . . . . . . 9

State Energy Data Report 1995 Consumption Estimates . . . . . . . . . . . . 9

State Energy Price and Expenditure Report 1994 . . . . . . . . . . . . . 9 


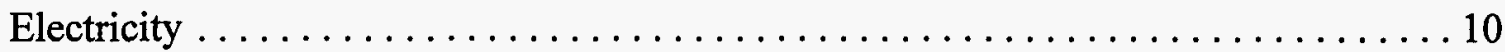

The Changing Structure of the Electric Power Industry: An Update $\ldots \ldots \ldots 10$

The Effects of Title IV of the Clean Air Act Amendments of 1990 on

Electric Utilities: An Update ......................... 10

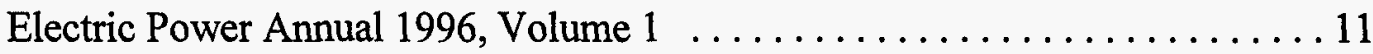

Electric Power Monthly ............................... 11

Electricity Prices in a Competitive Environment: Marginal Cost Pricing of

Generation Services and Financial Status of Electric Utilities ....... 11

Electricity Reform Abroad and U.S. Investment . . . . . . . . . . . . . . . 12

Electric Sales and Revenue 1995 . . . . . . . . . . . . . . . . . . . . . . . . 12

Electric Sales and Revenue 1996 .......................... 13

Financial Statistics of Major U.S. Investor-Owned Electric Utilities 1995 . . . . 13

Financial Statistics of Major U.S. Investor-Owned Electric Utilities 1996 . . . . 13

Financial Statistics of Major U.S. Publicly Owned Electric Utilities 1995 . . . . 14

Inventory of Power Plants in the United States As of January 1, 1996 . . . . . . 14

U.S. Electric Utility Demand-Side Management 1995 . . . . . . . . . . . . 15

U.S. Electric Utility Demand-Side Management $1996 \ldots \ldots \ldots \ldots \ldots \ldots 15$

Renewable Energy \& Alternative Fuels . . . . . . . . . . . . . . . . . . . . 15

Alternatives to Traditional Transportation Fuels $1996 \ldots \ldots \ldots \ldots \ldots \ldots \ldots$

Analysis of Carbon Stabilization Cases . . . . . . . . . . . . . . . 16

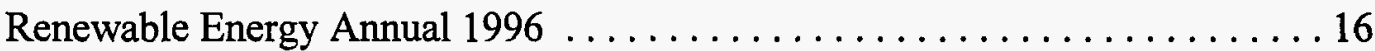

End-Use Consumption ................................... 17

Household Vehicles Energy Consumption 1994 . . . . . . . . . . . . . . . 17

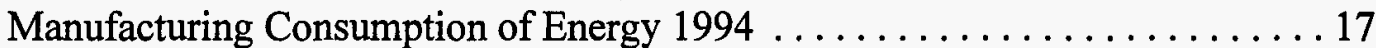

Models .......................................... 18

EIA Model Documentation: NEMS Integrating Module Documentation

Report .............................. 18

EIA Model Documentation: Petroleum Market Model of the National Energy

Modeling System ........................... 18

EIA Model Documentation: Coal Market Module of the National Energy

Modeling System ............................ 18

EIA Model Documentation: Natural Gas Transmission and Distribution Model of the National Energy Modeling System ............. 19

EIA Model Documentation: Documentation of the Oil and Gas Supply Module (OGSM) .............................. 19

EIA Model Documentation: Industrial Sector Demand Module of the

National Energy Modeling System ................... 19

Model Documentation Report: Industrial Sector Demand Module of the National Energy Modeling System .................. 20

Model Documentation Report: Macroeconomic Activity Module (MAM) of the National Energy Modeling System . ............... 20

Model Documentation Report: Commercial Sector Demand Module of the National Energy Modeling System ................... 20

Model Documentation Report: Residential Sector Demand Module of the National Energy Modeling System .................... 21 
Model Documentation Report: Residential Sector Demand Module of the National Energy Modeling System $\ldots \ldots \ldots \ldots \ldots \ldots \ldots .21$

EIA Model Documentation: Electricity Market Module Electricity Fuel Dispatch ........................ 21

Model Documentation: Renewable Fuels Module of the National Energy

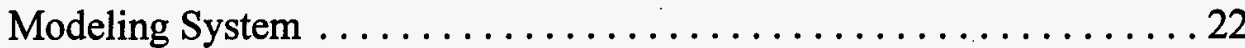
EIA Model Documentation: Transportation Sector Model of the

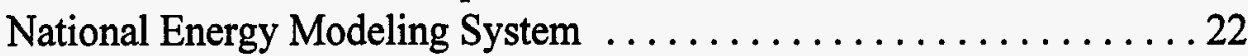

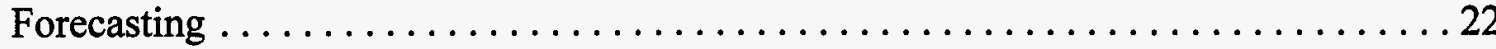

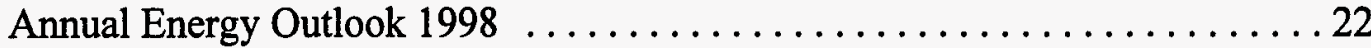

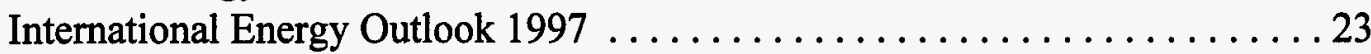

Issues in Midterm Analysis and Forecasting $1997 \ldots \ldots \ldots \ldots \ldots \ldots \ldots . \ldots . \ldots 23$

Short-Term Energy Outlook Quarterly Projections ............... 23

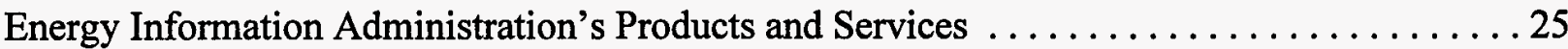

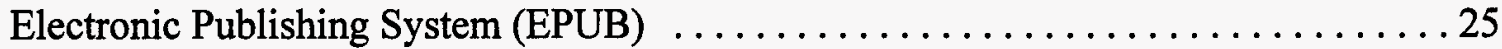

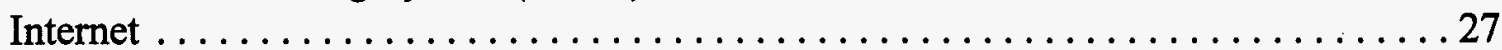

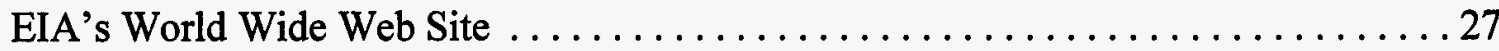

Electronic Mail List ........................................ 27

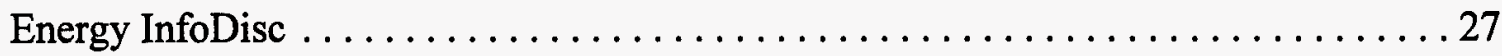

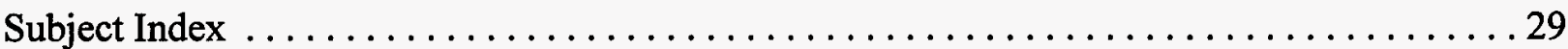

How to Order from the National Energy Information Center $\ldots \ldots \ldots \ldots \ldots \ldots \ldots \ldots$

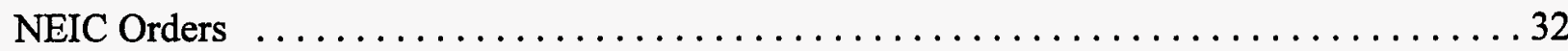




\section{Abstracts}

\section{MetaData}

\section{$1 \quad$ Annual Report to Congress 1996}

Section 205 of the Department of Energy Organization Act of 1977 established the Energy Information Administration (EIA). One of the mandates in this legislation is that EIA prepare for Congress an annual report summarizing both activities and information collected and published. EIA's major 1996 accomplishments are profiled in the body of this edition of the Annual Report to Congress. Appendix A contains abstracts of significant reports issued by EIA in 1996, and a chart of all titles and a list of all feature articles published during the year. Appendix B lists contact information for EIA subject matter specialists. Appendix $\mathrm{C}$ lists the major laws which form the basis of EIA's legislative mandate.

DOE/EIA-0173(96) Annual Jul 199752 pp.

\section{$2 \quad$ EIA Information Directory 1996}

The National Energy Information Center (NEIC), as part of its mission, provides energy information and referral assistance to Federal, State, and local governments, the academic community, business and industrial organizations, and the general public. The two principal functions related to this task are: 1) operating a general access telephone line, and 2) responding to energy-related correspondence addressed to the Energy Information Administration (EIA). The Energy Information Directory was developed to assist the NEIC staff, in directing inquiries to the proper offices within DOE, other Federal agencies, or energy-related trade associations.

DOE/EIA-0205(96) Annual Jan 1997104 pp.
3

EIA Information Directory 1997

The National Energy Information Center (NEIC), as part of its mission, provides energy information and referral assistance to Federal, State, and local governments, the academic community, business and industrial organizations, and the general public. The two principal functions related to this task are: 1) operating a general access telephone line, and 2) responding to energy-related correspondence addressed to the Energy Information Administration (EIA). The Energy Information Directory was developed to assist the NEIC staff, in directing inquiries to the proper offices within DOE, other Federal agencies, or energy-related trade associations.

DOE/EIA-0205(97) Annual Sep 1997116 pp.

\section{$4 \quad$ EIA New Releases}

The latest available EIA publications and upcoming reports are listed and described in this quarterly publication. Availability and ordering information are provided. News about EIA and other items of interest to users of EIA publications are also included. Beginning in January 1998, EIA will streamline the content and distribution of this publication. Rather than quarterly, this document will now be published monthly, but will be only one to two pages in length. It will contain a listing of information products released that month, with short abstracts and ordering information. It will be available only by Internet e-mail (listserve) or broadcast fax.

DOE/EIA-0204 Quarterly Available: NEIC

\section{$5 \quad$ EIA Publications Directory 1996}

This directory contains abstracts and ordering information for EIA publications released in 1996. The body of the Directory contains citations and abstracts arranged by broad subject categories; 
metadata, coal, oil and natural gas, nuclear and uranium, multifuel, electricity, renewable energy and alternative fuels, end-use consumption, models, and forecasting. Each abstract gives the title, report number, publication frequency, date, number of pages, and ordering information. Also included is a comprehensive subject index and description of EIA's products and services.

DOE/EIA-0149(96) Annual Apr 199744 pp.

\section{Energy Education Resources}

This publication is the result of a study undertaken by the National Energy Information Center (NEIC), a service of EIA, to provide its customers with a list of generally available free or low-cost energy-related educational materials for students and educators. This list is updated once a year. Some organizations now make their products available via computer. When available, Internet (Web) and electronic mail (E-mail) addresses were included in this year's edition. Each entry is followed by a number, which is referenced in the subject index in the back of the book.

DOE/EIA-0546(96) Annual Feb 1997132 pp.

\section{Coal}

\section{$7 \quad$ Coal Industry Annual 1996}

Coal Industry Annual 1996 (CIA) provides comprehensive information about U.S. coal production, number of mines, prices, productivity, employment, productive capacity, and recoverable reserves. U.S. coal production for 1996 and previous years is based on the annual survey EIA7A, "Coal Production Report." This report presents data on coal consumption, coal distribution, coal stocks, coal prices, coal quality, and emissions for Congress, Federal and State agencies, the coal industry, and the general public. Appendix A contains a compilation of coal statistics for the major coal-producing States.
This report does not include coal consumption data for nonutility power producers that are not in the manufacturing, agriculture, mining, construction, or commercial sectors.

DOE/EIA-0584(96) Annual Nov 1997272 pp. GPO Stock Number: 061-003-01011-3 GPO Price: $\$ 22.00$

\section{$8 \quad$ Quarterly Coal Report}

The Quarterly Coal Report (QCR) provides comprehensive information about U.S. coal production, distribution, exports, imports, receipts, prices, consumption, distribution, and stocks to a wide audience, including Congress, Federal and State agencies, the coal industry, and the general public. Coke production, consumption, distribution, imports, and exports data are also provided.

DOE/EIA-0121 Quarterly

GPO Subscription Price: $\$ 28.00$

\section{Oil and Natural Gas}

\section{An Analysis of U.S. Propane Markets Winter 1996-97}

This study constitutes an examination of propane supply, demand, and price developments and trends. EIA's approach focused on identifying the underlying reasons for the tight supply/demand balance in the fall of 1996 , and on examining the potential for a recurrence of these events next year. Because of the relative lack of public knowledge regarding propane supply, demand, and markets, it was decided that a comprehensive review of background material should be presented along with the study to enhance understanding of the relevant causes and consequences examined. Chapters 2, 3, and 4 of this report comprise an explanation of the fundamentals of propane supply, demand, and markets, largely for those readers not overly 
familiar with the industry.

DOE/EIA-SR/OOG/97-01 One-Time Jun 1997 $76 \mathrm{pp}$.

\section{$10 \quad$ Fuel Oil and Kerosene Sales 1996}

The Fuel Oil and Kerosene Sales 1996 report provides information, illustrations and State-level statistical data on end-use sales of kerosene; No. 1, No. 2, and No. 4 distillate fuel oil; and residual fuel oil. State-level kerosene sales include volumes for residential, commercial, industrial, farm, and all other uses. State-level distillate sales include volumes for residential, commercial, industrial, oil company, railroad, vessel bunkering, military, electric utility, farm, onhighway, off highway construction, and other uses. State-level residual fuel sales include volumes for commercial, industrial, oil company, vessel bunkering, military, electric utility, and other uses.

DOE/EIA-0535(96) Annual Aug 199768 pp. GPO Stock Number: 061-003-01004-1

GPO Price: $\$ 5.50$

\section{International Petroleum Statistics Report}

The International Petroleum Statistics Report (IPSR) is a monthly publication that provides current international oil data. This report is published for the use of Members of Congress, Federal and State agencies, industry, and the general public. This report presents data on international oil production, demand, imports, and stocks. The report has four sections. Section 1 contains time series data on world oil production, and on oil demand and stocks in the Organization for Economic Cooperation and Development (OECD). This section contains annual data beginning in 1985, and monthly data for the most recent two years. Section 2 presents an oil supply/demand balance for the world. This balance is presented in quarterly intervals for the most recent two years. Section 3 presents data on oil imports by OECD countries. This section contains annual data for the most recent year, quarterly data for the most recent two quarters, and monthly data for the most recent twelve months. Section 4 presents annual time series data on world oil production and oil stocks, demand, and trade in OECD countries.

DOE/EIA-0520 Monthly

GPO Subscription Price: $\$ 52.00$

\section{Motor Gasoline Assessment, Spring 1997}

The springs of 1996 and 1997 provide an excellent example of contrasting gasoline market dynamics. In spring 1996, tightening crude oil markets pushed up gasoline prices sharply, adding to the normal seasonal gasoline price increases; however, in spring 1997, crude oil markets loosened and crude oil prices fell, bringing gasoline prices down. This pattern was followed throughout the country except in California. As a result of its unique reformulated gasoline, California prices began to vary significantly from the rest of the country in 1996 and continued to exhibit distinct variations in 1997. In addition to the price contrasts between 1996 and 1997, changes occurred in the way in which gasoline markets were supplied. Low stocks, high refinery utilizations, and high imports persisted through 1996 into summer 1997, but these factors seem to have had little impact on gasoline price spreads relative to average spread.

DOE/EIA-0613 One-Time Jul 199776 pp.

GPO Stock Number: 061-003-01000-8

GPO Price: $\$ 6.50$

\section{$13 \quad$ Natural Gas Annual 1996}

The Natural Gas Annual (NGA) provides information on the supply and disposition of natural gas to a wide audience including industry, consumers, Federal and State agencies, and educational institutions. The 1996 data are presented in a sequence that follows natural gas 
(including supplemental supplies) from its production to its end use. This is followed by tables summarizing natural gas supply and disposition from 1992 to 1996 for each Census Division and each State. Annual historical data are shown at the national level. Two EIA surveys provide most of the information presented in this report -- the mandatory Form EIA-176, "Annual Report of Natural and Supplemental Gas Supply and Disposition," and the Form EIA-895, "Monthly Quantity and Value of Natural Gas Report." Form EIA-176 was submitted by respondents out of an identified universe of operators of fields, well, or natural gas processing plants who distribute gas to end users or transport gas to or across a State border; operators or synthetic natural gas plants; natural gas distributors; natural gas pipeline companies; and companies that operate underground natural gas storage facilities. Form EIA-895 was submitted by the appropriate agencies of the 33 natural gas producing States.

DOE/EIA-0131(96) Annual Sep 1997260 pp. GPO Stock Number: 061-003-01006-7

GPO Price: $\$ 21.00$

\section{Natural Gas Monthly}

The Natural Gas Monthly (NGM) highlights activities, events, and analyses of interest to public and private sector organizations associated with the natural gas industry. Volume and price data are presented each month for natural gas production, distribution, consumption, and interstate pipeline activities. Producer-related activities and underground storage data are also reported. From time to time, the $N G M$ features articles designed to assist readers in using and interpreting natural gas information.

DOE/EIA-0130 Monthly

GPO Subscription Price: $\$ 83.00$

\section{Oil and Gas Resources of the West Siberian Basin, Russia}

Oil and Gas Resources of the West Siberian Basin, Russia is part of the Energy Information Administration's (EIA's) Foreign Energy Supply Assessment Program (FESAP). The primary objective of this study is to assess the oil and gas potential of the West Siberian Basin of Russia. The study does not analyze the costs or technology necessary to achieve the estimates of the ultimate recoverable oil and gas. This is the second report on an oil and gas province in the former Soviet Union. The first, Oil and Gas Resources of the Fergana Basin (Uzbekistan, Tadzhikistan and Kyrgyzstan), was published in January 1995. This study uses reservoir data to estimate recoverable oil and gas quantities which were aggregated to the field level. Field totals were summed to a basin total for discovered fields. An estimate of undiscovered oil and gas, from work of the United States Geological Survey (USGS), was added to give a total basin resource volume. Recent production decline points out Russia's need to continue development of its discovered recoverable oil and gas. Continued exploration is required to discover additional oil and gas that remains undiscovered in the basin.

DOE/EIA-0617 One-Time Dec 1997228 pp.

GPO Stock Number: 061-003-01012-1

GPO Price: $\$ 19.00$

\section{Petroleum Marketing Monthly}

The Petroleum Marketing Monthly (PMM) provides information and statistical data on a variety of crude oils and refined petroleum products. The publication presents statistics on crude oil costs and refined petroleum products sales for use by industry, government, private sector analysts, educational institutions, and consumers. Data on crude oil include the domestic first purchase price, and the f.o.b. and landed cost of imported crude oil. Refined petroleum product sales include motor gasoline, distillates, residuals, aviation fuels, kerosene, and propane. 
DOE/EIA-0380 Monthly

GPO Subscription Price: $\$ 94.00$

\section{Petroleum Supply Annual 1996, Volume 1}

The Petroleum Supply Annual (PSA) contains information on the supply and disposition of crude oil and petroleum products. The publication reflects data that were collected from the petroleum industry during 1996 through annual and monthly surveys. The $P S A$ is divided into two volumes. This first volume contains three sections: Summary Statistics, Detailed Statistics, and Refinery Capacity; each with final annual data. The summary statistics section contains a summary of the data presented each month in the Petroleum Supply Monthly (PSM). Graphs and tables are provided which show 16 years of data depicting the balance between supply, disposition and ending stocks for various commodities including crude oil, motor gasoline, distillate fuel oil, residual fuel oil, jet fuel, propane/propylene, and liquefied petroleum gases. The detailed statistics section provides 1996 detailed statistics on supply and disposition, refinery operations, imports and exports, stocks, and transportation of crude oil and petroleum products. In most cases, the statistics are presented for several geographic areas -- the United States (50 States and the District of Columbia), five Petroleum Administration for Defense (PAD) Districts, and 12 Refining Districts. At the U.S. and PAD District level, the total volume and the daily rate of activities are presented. The tables contained in the refinery capacity section are compiled from the Form EIA-820 "Biennial Refinery Report." Of particular note are listings of refineries and associated crude oil distillation and downstream capacities by State, as of January 1997, as well as summaries of corporate refinery capacities and refinery storage capacities. In addition, refinery receipts of crude oil by method of transportation for 1996 are provided. Also included are fuels consumed at refineries, and lists of shutdowns, sales, reactivations, and mergers during 1995 and 1996.
DOE/EIA-0340(96)/1 Annual Jun $1997182 \mathrm{pp}$.

GPO Stock Number: 061-003-00996-4

GPO Price: $\$ 16.00$

\section{Petroleum Supply Annual 1996, Volume 2}

The Petroleum Supply Annual (PSA) contains information on the supply and disposition of crude oil and petroleum products. The publication reflects data that were collected from the petroleum industry during 1996 through annual and monthly surveys. The second volume contains final statistics for each month of 1996 , and replace data previously published in the Petroleum Supply Monthly (PSM). The tables in Volumes 1 and 2 are similarly numbered to facilitate comparison between them.

DOE/EIA-0340(96)/2 Annual Jun 1997608 pp.

GPO Stock Number: 061-003-00997-2

GPO Price: $\$ 47.00$

\section{Petroleum Supply Monthly}

The Petroleum Supply Monthly (PSM) is one of a family of four publications reflecting different levels of data timeliness and completeness. Data presented in the PSM describe the supply and disposition of petroleum products in the United States and major U.S. geographic regions. The data series describe production, imports and exports, inter-Petroleum Administration for Defense (PAD) District movements, and inventories by the primary suppliers of petroleum products in the United States (50 States and the District of Columbia). The reporting universe includes those petroleum sectors in primary supply. Included are: petroleum refiners, motor gasoline blenders, operators of natural gas processing plants and fractionators, inter-PADD transporters, importers, and major inventory holders of petroleum products and crude oil. When aggregated, the data reported by these sectors approximately represent the consumption of petroleum products in the United States. 
DOE/EIA-0109 Monthly

GPO Subscription Price: $\$ 85.00$

\section{Petroleum 1996: Issues and Trends}

This report addresses the phenomenon of volatility, which involves every aspect of the petroleum sector to differing degrees. More analysis of this and other petroleum-related topics can be conducted using the combination of data collected by EIA and available trade data. What EIA will address in the future, and how, depends on both market developments and on you, customers of the Energy Information Administration and users of this first edition of Petroleum 1996: Issues and Trends. Increasingly, users of the Energy Information Administration's petroleum data and analytical reports have expressed an interest in a recurring report that takes a broad view of the complex interrelationships that comprise an industry and markets accounting for 40 percent of the energy consumed in the United States and ranging from the drilling rig in the oil field to the pump at the local gasoline station. This report comprehensively examines historical trends, and selectively focuses on major issues and the events they represent. It analyzes different dimensions of the industry and related markets in terms of how they relate to a common theme, in this case, the volatility in petroleum markets.

DOE/EIA-0615 One-Time Sep 1997164 pp. GPO Stock Number: 061-003-01007-5

GPO Price: $\$ 13.00$

\section{U.S. Crude Oil, Natural Gas, and Natural Gas Liquids Reserves Annual Report 1996}

The U.S. Crude Oil, Natural Gas, and Natural Gas Liquids Reserves 1996 Annual Report is the 20th report prepared by the Energy Information Administration(EIA) to fulfill its responsibility to gather and report annual proved reserves estimates. The EIA annual reserves report series is the only source of comprehensive domestic proved reserves estimates. This publication is used by the Congress, Federal and State agencies, industry, and other interested parties to obtain accurate estimates of the Nation's proved reserves of crude oil, natural gas, and natural gas liquids. These data are essential to the development, implementation, and evaluation of energy policy and legislation. This report presents estimates of proved reserves of crude oil, natural gas and natural gas liquids as of December 31,1996 , as well as production volumes for the United States and selected States and State subdivisions for the year 1996. Estimates are presented for the following four categories of natural gas: total gas (wet after lease separation), nonassociated gas and associated-dissolved gas (which are the two major types of wet natural gas), and total dry gas (wet gas adjusted for the removal of liquids at natural gas processing plants). In addition, reserve estimates for two types of natural gas liquids, lease condensate and natural gas plant liquids, are presented. The estimates are based upon data obtained from two annual EIA surveys: Form EIA-23, "Annual Survey of Domestic Oil and Gas Reserves" and Form EIA-64A, "Annual Report of the Origin of Natural Gas Liquids Production." Also included is information on indicated additional crude oil reserves and crude oil, natural gas, and lease condensate reserves in nonproducing reservoirs. A discussion of notable oil and gas exploration and development activities during 1996 is provided.

DOE/EIA-0216(96) Annual Nov 1997158 pp. GPO Stock Number: 061-003-01015-6

GPO Price: $\$ 14.00$

\section{Weekly Petroleum Status Report}

The Weekly Petroleum Status Report (WPSR) provides timely information on the petroleum supply situation in the context of historical information, selected price, and forecasts. The WPSR is intended to provide up-to-date information to the industry, the press, planners, policymakers, consumers, analysts, and State and 
local governments. Shown are the U.S. petroleum balance sheet, refinery activity, stocks, imports, products supplied, and prices. Data cover: refinery inputs, utilization, and production; stocks of crude oil and major products (gasoline, distillate fuel oil, residual fuel oil, etc.) by Petroleum Administration for Defense District; refiner acquisition costs of crude oil; retail selling prices for motor gasoline and residential heating oil; world crude oil prices; and spot market product prices. Strategic Petroleum Reserve data are shown when appropriate. Appendix A presents explanatory notes and Appendix B presents the results of Form EIA-819, "Monthly Oxygenate Telephone Report." Appendix C includes the Winter Heating Fuels Summary.

DOE/EIA-0208 Weekly

GPO Subscription Price: $\$ 72.00$

\section{Nuclear and Uranium}

\section{$23 \quad$ Nuclear Power Generation and Fuel Cycle Report 1997}

This report provides information and forecasts important to the domestic and world nuclear and uranium industries. The first chapter presents the current status and projections through 2015 of nuclear capacity and generation for all countries with commercial nuclear power programs. U.S. capacity projections are consistent with those published in the Annual Energy Outlook 1997. Because of its robust growth in nuclear power, a special section on the Far East appears on colored sheets at the back of this chapter. The next chapter contains current information and projections on worldwide uranium requirements, enrichment service requirements and spent fuel discharges from 1997 to 2015 . The projections for U.S. spot-market prices, production, and imports are given to 2010. There is also a discussion of the U.S. uranium market analyzing how uranium purchases vary with spot-market prices. Information on deliveries of surplus Russian defense material is also presented in this chapter. The last chapter compares EIA's projections with those of Energy Resource International, Inc; and NAC International. The composition of this report differs from earlier versions. Previous reports contained discussions on current interest issues such as nuclear power plant performance and operations lifetime issues (1995) as well as decommissioning U.S. nuclear power plants (1996). In this report we confine our presentation to discussions of worldwide nuclear capacity, generation and the uranium market. New to Appendix A is a brief account of historical events that lead to the first self-sustaining nuclear reactor experiment. Detailed descriptions of the models used to make the fuel cycle projections are found in Appendix B. Also included in Appendix $\mathrm{C}$ are the nuclear generating units ordered in the United States from 1953 to 1996. Appendix F contains detailed reference case forecasts of nuclear fuel cycle requirements along with the low and high case capacity projections.

DOE/EIA-0436(97) Annual Sep 1997136 pp. GPO Stock Number: 061-003-01005-9

GPO Price: $\$ 11.00$

\section{$24 \quad$ Uranium Industry Annual 1996}

The Uranium Industry Annual 1996 (UIA) provides current statistical data on the U.S. uranium industry's activities relating to uranium raw materials and uranium marketing. The UIA 1996 is prepared for use by the Congress, Federal and State agencies, the uranium and nuclear electric utility industries, and the public. It contains data for the period 1987 through 2006 as collected on the Form EIA-858, "Uranium Industry Annual Survey." Data collected on the "Uranium Industry Annual Survey" provide a comprehensive statistical characterization of the industry's activities for the survey year and also include some information about industry's plans and commitments for the near-term future. Where aggregate data are presented in the ULA 1996, care has been taken to protect the confidentiality of company-specific information while still conveying accurate and complete statistical data. 
DOE/EIA-0478(96) Annual Apr 199788 pp.

GPO Stock Number: 061-003-00994-8

GPO Price: $\$ 8.00$

\section{Multifuel}

\section{$25 \quad$ Annual Energy Review 1996}

The Annual Energy Review 1996 (AER) is a compendium of historical energy statistics. It draws together the most important statistical series from all of the major energy sources, presents them in data tables and graphs, and uses them to create summary statistics for all energy. It is the objective of the Energy Information Administration (EIA) with this report to distill the vast amount of historical data available into clear and well-organized presentations that invite the reader's interest and offer the opportunity to learn about this Nation's energy history in order to prepare for our future. Many of the data series in this report run from 1949 through 1996, providing nearly a half-century of data for analysis of longterm trends.

DOE/EIA-0384(96) Annual Jun 1997416 pp. GPO Stock Number: 061-003-00998-1

GPO Price: $\$ 33.00$

\section{Emissions of Greenhouse Gases in the United States 1996}

The Energy Information Administration (EIA) is required by the Energy Policy Act of 1992 to prepare a report on aggregate U.S. national emissions of greenhouse gases for the period 1987-1990, with annual updates thereafter. This report is the fifth annual update covering national emissions over the period 1989-1995, with preliminary estimates of emissions for 1996 . The estimates contained in this report have been revised from those in last year's report. Emissions estimates for carbon dioxide are reported in metric tons of carbon; estimates for others gases are reported in metric tons of gas.
Chapter 1 of this report briefly recapitulates some background information about global climate changes and the greenhouse effect and discusses important recent developments in global climate change activities. Chapters 2 through 6 cover emissions of carbon dioxide, methane, nitrous oxide, halocarbons, and criteria pollutants, respectively. Chapter 7 describes potential sequestration and emissions of greenhouse gases as a result of land use changes.

DOE/EIA-0573(96) Annual Oct 1997156 pp. GPO Stock Number: 061-003-01008-3

GPO Price: $\$ 12.00$

\section{Mitigating Greenhouse Gas Emissions: Voluntary Reporting}

The Voluntary Reporting Program, developed pursuant to Section 1605(b) of the Energy Policy Act of 1992, permits corporations, government agencies, households, and voluntary organizations to report on their emissions of greenhouse gases, and on actions taken that have reduced or avoided emissions or sequestered carbon, to the Energy Information Administration (EIA). This, the second annual report of the Voluntary Reporting Program, describes information provided by the participating organizations on their aggregate emissions and emissions reductions, as well as their emissions reduction or avoidance projects, through 1995. This information has been compiled into a database that includes reports from 142 organizations and descriptions of 967 projects that either reduced greenhouse gas emissions or sequestered carbon. Fifty-one reporters also provided estimates of emissions, and emissions reductions achieved, for their entire organizations.

DOE/EIA-0608(96) Annual Oct 1997128 pp.

\section{$28 \quad$ Monthly Energy Review}

The Monthly Energy Review (MER) presents an overview of recent monthly energy statistics. The statistics cover the major activities of U.S. 
production, consumption, trade, stocks, and prices for petroleum, natural gas, coal, electricity, and nuclear energy. Also included are international energy and thermal and metric conversion factors. The $M E R$ is intended for use by Congress, Federal and State agencies, energy analysts, and the general public.

DOE/EIA-0035 Monthly

GPO Subscription Price: $\$ 87.00$

\section{Performance Profiles of Major Energy Producers 1995}

This publication examines developments in the operations of the major U.S. energy-producing companies on a corporate level, by major line of business, by major function within each line of business, and by geographic area. This report presents financial and operational data collected on Form EIA-28, "Financial Reporting System (FRS)," for the calendar year 1995. Trends in foreign direct investment in U.S. energy are analyzed for the year 1994. In 1995, 24 companies filed Form EIA-28. The analysis and data presented in this report represent the operations of the FRS companies in the context of their worldwide operations and in the context of the major energy markets which they serve. Both energy and nonenergy developments of these companies are analyzed. Although the focus is on developments in 1995, important trends prior to that time are also featured.

DOE/EIA-0206(95) Annual Jan 1997192 pp. GPO Stock Number: 061-003-00989-1

GPO Price: $\$ 16.00$

\section{$30 \quad$ State Energy Data Report 1995 Consumption Estimates}

The State Energy Data Report 1995 (SEDR) provides annual time series estimates of Statelevel energy consumption by major economic sectors. The estimates are developed in the State Energy Data System (SEDS), which is maintained and operated by the Energy Information
Administration (EIA). The goal in maintaining SEDS is to create historical time series of energy consumption by State that are defined as consistently as possible over time and across sectors. SEDS exists for two principal reasons: (1) to provide State energy consumption estimates to Members of Congress, Federal and State agencies, and the general public and (2) to provide the historical series necessary for EIA's energy models. The $S E D R$ presents estimates of annual energy consumption at the State and national levels by major economic sector and by principal energy type for 1960 and 1970 through 1995. Included in the report are documentation describing how the estimates were made for each type of energy, the source references for all input data, and a summary of changes from the State Energy Data Report 1994 published in October 1996.

DOE/EIA-0214(95) Annual Dec 1997548 pp. GPO Stock Number: 061-003-01013-0

GPO Price: $\$ 43.00$

\section{State Energy Price and Expenditure Report 1994}

The State Energy Price and Expenditure Report 1994 (SEPER) presents energy price and expenditure estimates individually for the 50 States and the District of Columbia and in aggregate for the United States. The price and expenditure estimates developed in the State Energy Price and Expenditure Data System (SEPEDS) are provided by energy source and economic sector and are published for the years 1970 through 1994. Data for all years are available on personal computer diskettes, CDROM, and via Internet.

DOE/EIA-0376(94) Annual Jun 1997460 pp.

GPO Stock Number: 061-003-00995-6

GPO Price: $\$ 35.00$ 


\section{Electricity}

\section{The Changing Structure of the Electric Power Industry: An Update}

The purpose of this report, which is intended for both lay and technical readers, is twofold. First, it is a basic reference document that provides a comprehensive delineation of the electric power industry and its traditional structure, which has been based upon its monopoly status. Second, it describes the industry's transition to a competitive environment by providing a descriptive analysis of the factors that have contributed to the interest in a competitive market, proposed legislative and regulatory actions, and the steps being taken by the various components of the industry to meet the challenges of adapting to and prevailing in a competitive environment. In order to facilitate the presentation, the report is divided into two parts. Part I provides a historical overview of the electric power industry -- a requisite piece to the changing structure puzzle. Before the transitional state of the current industry can be fully comprehended, it is necessary to understand the conventional roles of the components of electricity supply and factors that have affected them from the beginning, including legislative and regulatory mandates, advancing technologies, and fluctuating economic conditions. To that end, the overview section presents an abridged version of the industry's history, touching on the events that have had the most profound effect on its structure. Also included is an in-depth look at the industry's current structure and its generating, transmitting, and distributing components. The substantially involved subject of utility and nonutility organizational entities and their roles and relationships is examined in detail to provide an essential basic understanding of the supply component terms used throughout this report. Major legislation that has had the most profound impact on the structure of the industry over the years is discussed, and the discussion is accompanied by a table summarizing each law's requirements along with additional laws that have had significant effects on power suppliers. The entirety of Part I was designed to be a convenient handbook that can be continually referenced to answer questions concerning the fundamentals of the electric power industry. Part II addresses the current restructuring issues and events. It outlines the forces behind the drive to restructure. The legislative proposals for reform and restructuring that have been introduced into the U.S. Congress are cited and summarized, and the Federal and State roles in promoting competition through regulatory reform are described. The issue of stranded costs -- that is, the costs utilities have prudently incurred to serve their customers but which cannot be recovered if the customers choose other electricity suppliers -- are examined. Strategies to recover such costs are discussed, along with the question of who will bear the costs. In addition, Part II presents a detailed discussion of industry plans and developments that are emerging as a direct result of the move toward competition, including strategies to lower costs and other actions planned or already taken by major investor-owned utilities to prepare for competition. Likewise, the tactics of public utilities and cooperative utilities are examined.

DOE/EIA-0562(96) One-Time Jan 1997196 pp. GPO Stock Number: 061-003-00982-4

GPO Price: $\$ 15.00$

\section{The Effects of Title IV of the Clean Air Act Amendments of 1990 on Electric Utilities: An Update}

The Clean Air Act Amendments of 1990 address numerous air quality problems in the United States that were not entirely covered in earlier legislation. One of these problems is acid rain caused by sulfur dioxide $\left(\mathrm{SO}_{2}\right)$ and nitrogen oxides $\left(\mathrm{NO}_{\mathrm{x}}\right)$ emissions from fossil-fueled electric power plants and, to a lesser extent, from other industrial and transportation sources. Title IV of the Act created a two-phased plan, administered by the U.S. Environmental Protection Agency (EPA), to reduce acid rain in the United States. Phase I runs from 1995 through 1999, and Phase 
II, which is more stringent Phase I, begins in 2000. Title IV contains a table listing 261 generating units that are required to comply with Phase I. They are generally referred to by EPA as Table 1 units. Most of these units are coal fired with relatively high emissions. An additional 174 units are participating in Phase I based on the rules established by EPA, allowing a utility to designate substitution or compensating units as part of their Phase I compliance plans. Therefore, 435 units are now considered Phase I units. More than 2,000 units will be affected by Phase II. This report updates and expands a report published by the Energy Information Administration in 1994 titled, Electric Utility Phase I Acid Rain Compliance Strategies for the Clean Air Act Amendments of 1990; it describes the strategies used to comply with the Acid Rain Program in 1995, the effect of compliance on $\mathrm{SO}_{2}$ emissions levels, the cost of compliance, and the effects of the program on coal supply and demand.

DOE/EIA-0582(97) One-Time Mar 1997128 pp. GPO Stock Number: 061-003-00990-5

GPO Price: $\$ 9.50$

\section{Electric Power Annual 1996, Volume 1}

The Electric Power Annual (EPA) presents a summary of electric power industry statistics at national, regional, and State levels. The objective of the publication is to provide industry decisionmakers, government policy-makers, analysts, and the general public with data that may be used in understanding U.S. electricity markets. Volume 1 focuses on U.S. electric utilities and contains final 1996 data on net generation and fossil fuel consumption, stocks, receipts, and cost; preliminary 1996 data on generating unit capability, and retail sales of electricity, associated revenue, and the average revenue per kilowatthour of electricity sold. Additionally, information on net generation from renewable energy sources and on the associated generating capability is included in Volume 1 of the $E P A$. Data published in the Electric Power Annual Volume 1 are compiled from three statistical forms filed monthly and two forms filed annually by electric utilities.

DOE/EIA-0348(96)/1 Annual Aug 199772 pp. GPO Stock Number: 061-003-01003-2

GPO Price: $\$ 5.50$

\section{Electric Power Monthly}

The Electric Power Monthly (EPM) presents monthly electricity statistics for a wide audience including Congress, Federal and State agencies, the electric utility industry, and the general public. The purpose of this publication is to provide energy decisionmakers with accurate and timely information that may be used in forming various perspectives on electric issues that lie ahead. The EIA collected the information in this report to fulfill its data collection and dissemination responsibilities as specified in the Federal Energy Administration Act of 1974 (Public Law 93-275) as amended.

DOE/EIA-0226 Monthly

GPO Subscription Price: $\$ 89.00$

\section{Electricity Prices in a Competitive Environment: Marginal Cost Pricing of Generation Services and Financial Status of Electric Utilities}

The report contains five chapters. Chapter 1 includes a description of the events that led to current initiatives to restructure the electric power industry, as well as a discussion of the institutional and structural changes that will be required to support the competitive pricing of electricity. Chapter 2 describes the analysis assumptions and methodology. Chapter 3 discusses the uses and results of the analysis, including a comparison of electricity prices under regulation and prices under competition and a discussion of the sensitivities of the results to key parameters in the analysis cases. Chapter 4 contains an analysis of the cash flow implications 
of the new competitive prices for utilities. Chapter 5 includes a conclusion and a final word on the limitations of the analysis. The Appendices provide technical descriptions of the methodology used to calculate competitive electricity prices. This report is intended for a general audience. It should be of particular interest to public utility analysts, policy and financial analysts, investment firms, trade associations, Federal and State regulators, and legislators.

DOE/EIA-0614 One-Time Aug 1997126 pp. GPO Stock Number: 061-003-01002-4

GPO Price: $\$ 10.00$

\section{Electricity Reform Abroad and U.S. Investment}

Over the past few years, several nations have initiated electricity industry reform and privatization efforts. Argentina, Australia, and the United Kingdom (UK) are among those countries at the forefront of such efforts. Reforms undertaken in these three countries are especially important because they have in many ways become models for reforms carried out elsewhere. From the perspective of the United States (and other countries considering electricity reform), these three nations are often viewed as laboratories in which the efficiency of particular electricity reform policy choices are being tested. For this reason, we have referred to these reforms as "experiments". In reality, however, these reforms represent firm policy measures adopted by the countries involved. This report reviews and analyzes the recent electricity reforms in these countries in an attempt to better understand how different models of privatization and reform have worked in practice. This report also analyzes the motivations of the U.S. companies who have invested in the electricity industries of Argentina, Australia, and the UK. These countries have become the largest targets of U.S. foreign investment in electricity. American electricity investment in the newly-privatized electricity industries of Australia and the UK far exceed all other U.S. electricity investment abroad. Companies from the United States were also the largest investors in Argentina's recentlyprivatized electric utility industry. This report utilized two calculations of foreign investment. One is the foreign investment series produced by the U.S. Department of Commerce. The other is based on transactions (compiled from the financial press) in Argentine, Australian, and U.K. electric utilities. The electricity reform and privatization experiences reviewed in this report may offer some insight as to how the U.S. electricity industry might develop as a result of recent domestic reform efforts and deregulation at both the State and national levels.

DOE/EIA-0616 One-Time Oct 1997124 pp. GPO Stock Number: 061-003-01009-1

GPO Price: $\$ 9.50$

\section{$38 \quad$ Electric Sales and Revenue 1995}

Information is provided on electricity sales, associated revenue, average revenue per kilowatthour sold, and number of consumers throughout the United States. The data provided in the Electric Sales and Revenue are presented at the national, Census division, State, and electric utility levels. The information is based on annual data reported by electric utilities for the calendar year ending December 31, 1995. In the private sector, users of the Electric Sales and Revenue include researchers, analysts, and member of the electric power industry community. Other users include financial and investment institutions, economic development organizations, special interest groups, lobbyists, electric power associations, and the news media. In the public sector, users include analysts, researchers, statisticians, and other professionals engaged in regulatory, policy, and program activities for Federal, State, and local governments. Congress, and other special government groups also use information on general trends related to electricity at State and national levels. Data in this report are used in analytical studies to evaluate new legislation and regulatory alternatives and to forecast demand for electric power. 
DOE/EIA-0540(95) Annual Jan 1997240 pp. GPO Stock Number: 061-003-00987-5

GPO Price: $\$ 19.00$

\section{$39 \quad$ Electric Sales and Revenue 1996}

Information is provided on electricity sales, associated revenue, average revenue per kilowatthour sold, and number of consumers throughout the United States. The data provided in the Electric Sales and Revenue are presented at the national, Census division, State, and electric utility levels. The information is based on annual data reported by electric utilities for the calendar year ending December 31, 1996. In the private sector, users of the Electric Sales and Revenue include researchers, analysts, and members of the electric power industry community. Other users include financial and investment institutions, economic development organizations, special interest groups, lobbyists, electric power associations, and the news media. In the public sector, users include analysts, researchers, statisticians, and other professionals engaged in regulatory, policy, and program activities for Federal, State, and local governments. Congress, and other special government groups also use information on general trends related to electricity at State and national levels. Data in this report are used in analytical studies to evaluate new legislation and regulatory alternatives and to forecast demand for electric power.

DOE/EIA-0540(96) Annual Dec 1997246 pp. GPO Stock Number: 061-003-01020-2

GPO Price: $\$ 19.00$

\section{Financial Statistics of Major U.S. Investor-Owned Electric Utilities 1995}

The Financial Statistics of Major U.S. InvestorOwned Electric Utilities publication presents summary and detailed financial accounting data on the investor-owned electric utilities. The objective of the publication is to provide Federal and State governments, industry, and the general public with current and historical data that can be used for making policy and decisions relating to investor-owned electric utility issues. Financial statistics for major investor-owned electric utilities have been compiled and published annually since 1938 to satisfy the requirements for accurate, readily available data regarding the electric power industry. The format was designed to be used by a variety of private, electric power industry, and government users. The publication contents and format have evolved over the years to better serve the needs and requirements of the targeted audience. The Financial Statistics of Major U.S. Investor-Owned Electric Utilities publication provides information about the financial results of operations of investor-owned electric utilities for use by government, industry, electric utilities, financial organizations and educational institutions in energy planning. In the private sector, the readers of this publication are researchers and analysts associated with the financial markets, the policymaking and decisionmaking members of electric utility companies, and economic development organizations. Other organizations that may be interested in the data presented in this publication include manufacturers of electric power equipment and marketing organizations. In the public sector, the readers of this publication include analysts, researchers, statisticians, and other professionals engaged in regulatory, policy, and program areas. These individuals are generally associated with the Congress, other legislative bodies, State public service commissions, universities, and national strategic planning organizations.

DOE/EIA-0437(95)/1 Annual Jan 1997628 pp. GPO Stock Number: 061-003-00980-8

GPO Price: $\$ 45.00$

\section{Financial Statistics of Major U.S. Investor-Owned Electric Utilities 1996}

The Financial Statistics of Major U.S. InvestorOwned Electric Utilities publication presents summary and detailed financial accounting data 
on the investor-owned electric utilities. The objective of the publication is to provide Federal and State governments, industry, and the general public with current and historical data that can be used for making policy and decisions relating to investor-owned electric utility issues. Financial statistics for major investor-owned electric utilities have been compiled and published annually since 1938 to satisfy the requirements for accurate, readily available data regarding the electric power industry. The format was designed to be used by a variety of private, electric power industry, and government users. The publication contents and format have evolved over the years to better serve the needs and requirements of the targeted audience. The Financial Statistics of Major U.S. Investor-Owned Electric Utilities publication provides information about the financial results of operations of investor-owned electric utilities for use by government, industry, electric utilities, financial organizations and educational institutions in energy planning. In the private sector, the readers of this publication are researchers and analysts associated with the financial markets, the policymaking and decisionmaking members of electric utility companies, and economic development organizations. Other organizations that may be interested in the data presented in this publication include manufacturers of electric power equipment and marketing organizations. In the public sector, the readers of this publication include analysts, researchers, statisticians, and other professionals engaged in regulatory, policy, and program areas. These individuals are generally associated with the Congress, other legislative bodies, State public service commissions, universities, and national strategic planning organizations.

DOE/EIA-0437(96)/1 Annual Dec 1997632 pp. GPO Stock Number: 061-003-01017-2

GPO Price: $\$ 49.00$

\section{Financial Statistics of Major U.S. Publicly Owned Electric Utilities 1995}

The 1995 edition of the Financial Statistics of Major U.S. Publicly Owned Electric Utilities publication presents 5 years (1991 through 1995) of summary financial data and current year detailed financial data on the major publicly owned electric utilities. The objective of this publication is to provide Federal and State governments, industry, and the general public with current and historical data that can be used for policymaking and decisionmaking purposes related to publicly owned electric utility issues.

DOE/EIA-0437(95)/2 Annual Jul 1997572 pp. GPO Stock Number: 061-003-00992-1

GPO Price: $\$ 46.00$

\section{Inventory of Power Plants in the United States As of January 1, 1996}

The Inventory of Power Plants in the United States As of January 1, 1996 provides annual statistics on generating units operated by electric utilities in the United States (the 50 States and the District of Columbia). Statistics presented in this report reflect the status of generating units as of January 1,1996 . The publication also provides a 10-year outlook for generating unit additions. Data summarized in this report are useful to a wide audience including Congress; Federal and State agencies; the electric utility industry; and the general public. Data presented in this report were assembled and published by the EIA to fulfill its data collection and dissemination responsibilities as specified in the Federal Energy Administration Act of 1974 (Public Law 93-275) as amended.

DOE/EIA-0095(96) Annual Jan 1997416 pp. GPO Stock Number: 061-003-00983-2

GPO Price: $\$ 29.00$ 


\section{$44 \quad$ U.S. Electric Utility Demand-Side Management 1995}

The report presents comprehensive information on electric power industry demand-side management (DSM) activities in the United States at the national, regional, and utility levels. The objective of the publication is to provide industry decision makers, government policy makers, analysts, and the general public with historical data that may be used in understanding DSM as it relates to the U.S. electric power industry. The first chapter, "Profile: U.S. Electric Utility Demand-Side Management," presents a general discussion of DSM, its history, current issues, and a review of key statistics for the year. Subsequent chapters present discussions and more detailed data on energy savings, peak load reductions and costs attributable to DSM. In the private sector, the majority of users are researchers, analysts, and ultimately the policymaking and decisionmaking members of electric utility companies. Financial and investment institutions, economic development organizations interested in new power plant construction, special interest groups, lobbyists, electric power associations, and the news media are all prospective users of the U.S. Electric Utility Demand-Side Management report. In the public sector, users include analysts, researchers, statisticians, and other professionals engaged in regulatory, policy, and program activities for Federal, State, and local governments. The Congress, other legislative bodies, State public service commissions, and other government groups share an interest in general trends and specific DSM data. This report can be used in analytic studies to evaluate new or existing legislation.

DOE/EIA-0589(95) Annual Feb 1997108 pp.

\section{U.S. Electric Utility Demand-Side Management 1996}

The report presents comprehensive information on electric power industry demand-side management (DSM) activities in the United States at the national, regional, and utility levels. The objective of the publication is to provide industry decision makers, government policy makers, analysts, and the general public with historical data that may be used in understanding DSM as it relates to the U.S. electric power industry. The first chapter, "Profile: U.S. Electric Utility Demand-Side Management," presents a general discussion of DSM, its history, current issues, and a review of key statistics for the year. Subsequent chapters present discussions and more detailed data on energy savings, peak load reductions and costs attributable to DSM. In the private sector, the majority of users are researchers, analysts, and ultimately the policymaking and decisionmaking members of electric utility companies. Financial and investment institutions, economic development organizations interested in new power plant construction, special interest groups, lobbyists, electric power associations, and the news media are all prospective users of the U.S. Electric Utility Demand-Side Management report. In the public sector, users include analysts, researchers, statisticians, and other professionals engaged in regulatory, policy, and program activities for Federal, State, and local governments. The Congress, other legislative bodies, State public service commissions, and other government groups share an interest in general trends and specific DSM data. This report can be used in analytic studies to evaluate new or existing legislation.

DOE/EIA-0589(96) Annual Dec 1997108 pp. GPO Stock Number: 061-003-01021-1

GPO Price: $\$ 9.00$

\section{Renewable Energy \& Alternative Fuels}

\section{Alternatives to Traditional Transportation Fuels 1996}

Interest in the alternative transportation fuels (ATF's) has increased in recent years due to the drives for cleaner air and less dependence upon foreign oil. This report, Alternatives to 
Traditional Transportation Fuels 1996, provides information on ATF's, as well as the vehicles that consume them. This report has its roots in Section 503 of the Energy Policy Act of 1992 (EPACT), which directs the Energy Information Administration (EIA) to provide the U.S. Department of Energy (DOE) and the Congress with the following information on alternativefueled vehicles (AFV's) and ATF's: (1) the number, type, and geographic distribution of AFV's in use; (2) the consumption of ATF's and "replacement fuels"; (3) the number and type of AFV's "made available". Section 503 further specifies that information about these subjects is to be provided annually for the "current" and "following" years; i.e., the most recent historical year and an outlook for the next year. Since EPACT was passed in response to concerns about energy security (occasioned by the 1991 Persian Gulf conflict), its focus is on energy efficiency and improving domestic energy supplies. Clean air data and issues related to transportation fuels (except for requiring DOE to report on the greenhouse gas emissions resulting from ATF consumption) are addressed in the Clean Air Act Amendments of 1990 and are not discussed in this report.

DOE/EIA-0585(96) Annual Dec 199772 pp. GPO Stock Number: 061-003-01016-4

GPO Price: $\$ 6.00$

\section{Analysis of Carbon Stabilization Cases}

This study was undertaken at the request of the U.S. Department of Energy (DOE), Office of Policy and International Affairs (PO). Carbon mitigation and climate change are issues that must be addressed on a global scale by the international community. This study contributes to the analytical process by examining the impact of several carbon stabilization scenarios on the U.S. energy-economy. One set of cases extensively analyzes the impacts on the U.S. system assuming that carbon stabilization is achieved without the benefit of flexible international trading policies. The second sensitivity estimates the impacts on the U.S. energy-economy system of a much lower carbon value that may be realized under more flexible trading and other comprehensive approaches. Each member of the international community is expected to evaluate its options in a similar way prior to signing any international commitment to control carbon emissions. International emissions trading and a comprehensive approach to greenhouse gases are key elements of the U.S. position within the current international trading and a comprehensive approach to greenhouse gases are key elements of the U.S. position within the current international negotiations on climate. The DOE Office of Policy and International Affairs was a participant in the analytical effort of the Interagency Analysis Team (IAT) studying the economic effects of global climate change policies in the United States. DOE/PO requested the analysis of several carbon policy scenarios using the National Energy Modeling System (NEMS) to examine how carbon stabilization could be achieved by 2010 and beyond.

DOE/EIA-SR-OIAF/97-01 One-Time Oct 1997 $112 \mathrm{pp}$.

\section{$48 \quad$ Renewable Energy Annual 1996}

This report, the Renewable Energy Annual 1996, is the second in a series of annual reports published by the Energy Information Administration (EIA) to provide current information on renewable energy worldwide. In so doing, this report updates the information presented in the Renewable Energy Annual 1995 and further documents and explains renewable energy information provided in EIA's Annual Energy Review 1995. In addition, this report extends the scope of the previous issue by providing descriptive information on various segments of the renewable energy industry and discussions of new or ongoing renewable energy projects, as well as discussions of emerging economic and legal issues that affect the industry. It covers the following energy sources: biomass, geothermal, wind, and solar. While hydropower is a renewable energy resource, it is also regarded 
as a "conventional" energy source because it has furnished a significant amount of electricity for more than a century. Therefore, this report discusses hydropower as it contributes to total renewable energy consumption, but does not address hydropower as an individual energy source. Also, EIA collects data only on terrestrial systems. Satellite and military applications are not included in this report. The biomass sections of this report include updated information similar to that published in EIA's Estimates of U.S. Biomass Energy Consumption 1992. The solar sections include information similar to that previously published in Solar Collector Manufacturing Activity 1993. EIA has discontinued publishing the latter two reports.

DOE/EIA-0603(96) Annual Apr 1997200 pp. GPO Stock Number: 061-003-00991-3

GPO Price: $\$ 16.00$

\section{End-Use Consumption}

\section{Household Vehicles Energy Consumption 1994}

Household Vehicles Energy Consumption 1994 reports on the results of the 1994 Residential Transportation Energy Consumption Survey (RTECS). The RTECS is a national sample survey that has been conducted every 3 years since 1985 . For the 1994 survey, more than 3,000 households that own or use some 6,000 vehicles provided information to describe vehicle stock, vehicle-miles traveled, energy end-use consumption, and energy expenditures for personal vehicles. The survey results represent the characteristics of the 84.9 million households that used or had access to vehicles in 1994 nationwide. (An additional 12 million households neither owned nor had access to vehicles during the survey year.) To be included in the RTECS survey, vehicles must be either owned or used by household members on a regular basis for personal transportation, or owned by a company rather than a household, but kept at home, regularly available for the use of household members. Most vehicles included in the RTECS are classified as "light-duty vehicles" (weighing less than 8,500 pounds). However, the RTECS also includes a very small number of "other" vehicles, such as motor homes and larger trucks that are available for personal use. The survey results have implications for the overall fuel economy of the United States and the amount of motor gasoline consumed. The increase in the number of minivans, sport-utility vehicles, and pickup trucks may depress overall fleet fuel economy, because these vehicles are subject to the fuel economy standards for light trucks and consume more fuel per mile traveled. Fuel economy is increased, however, by the retirement of older vehicles that are less fuel efficient than newer models. Passenger cars built afer 1979 showed a dramatic increase in fuel economy, which rose 3 miles per gallon between 1979 and 1980 and then increased steadily -- though less dramatically -- throughout the 1980's. Fuel economy has leveled off in the 1990's. In 1991, 35 million vehicles, or 23 percent of the total vehicle stock, were from model year 1979 or earlier. By 1994, that number had dropped to 20 million, or 13 percent of the vehicle stock. Those older vehicles tend to be driven fewer miles than the new vehicles that replaced them, according to the survey data. Therefore, although older vehicles tend to consume more fuel per mile, their effect on the fleet average is mitigated by the fact that they are driven fewer miles.

DOE/EIA-0464(94) Triennial Jul 1997136 pp. GPO Stock Number: 061-003-01001-6

GPO Price: $\$ 10.00$

\section{0 \\ Manufacturing Consumption of Energy 1994}

Manufacturing Consumption of Energy 1994 provides estimates on energy consumption in the manufacturing sector of the U.S. economy. The estimates are based on data from the 1994 Manufacturing Energy Consumption Survey (MECS). The MECS, administered by the Energy Information Administration (EIA), is the most 
comprehensive source of national-level data on energy-related information about the manufacturing industries. To determine how energy is used in the manufacturing sector, EIA gathers information from a national representative sample of the manufacturing establishments that transform input materials or substances into new products, assemble components, or perform blending operations. In 1994, of the approximately 380 thousand manufacturing establishments in the United States, the MECS sample represented about 250 thousand of the largest establishments. Those establishments account for approximately 98 percent of U.S. economic output from manufacturing and an expected similar proportion of manufacturing energy use. The amount of energy an establishment uses is collected for all of its operations and not solely for the amount of energy used in manufacturing its product. The 1994 MECS is EIA's fourth survey of the manufacturing sector. Previous manufacturing surveys were conducted in 1986, 1989, and 1992 (for reporting years 1985, 1988, and 1991, respectively). The next manufacturing survey will be conducted for reporting year 1998, with subsequent surveys being conducted every 4 years thereafter.

DOE/EIA-0512(94) Triennial Dec 1997542 pp. GPO Stock Number: 061-003-01018-1

GPO Price: $\$ 41.00$

\section{Models}

\section{EIA Model Documentation: NEMS Integrating Module Documentation Report}

Publication of this document is supported by Public Law 93-275, Federal Energy Administration Act of 1974, Section 57.b.1 (as amended by Public Law 94-385, Energy Conservation and Production Act). In particular, this report is designed to meet EIA's model documentation standards established in accordance with these laws. For documentation purposes, the individual components of NEMS are considered distinct models and documented individually. While the NEMS integrating module is a distinct component of NEMS, the integrating module is not by itself, a model. Rather, it is a component of the overall NEMS model and implements specific aspects of the overall modeling methodology that are not documented elsewhere. The documentation is organized accordingly.

DOE/EIA-M057(97) One-Time Mar 199793 pp.

\section{EIA Model Documentation: Petroleum Market Model of the National Energy Modeling System}

The purpose of this report is to define the objectives of the Petroleum Market Model (PMM), describe its basic approach, and provide detail on how it works. This report is intended as a reference document for model analysts, users, and the public. Documentation of the model is in accordance with EIA's legal obligations to provide adequate documentation in support of its models (Public Law 94-385, Section 57.b.2).

DOE/EIA-M059(97) One-Time Mar 1997 $300 \mathrm{pp}$.

\section{EIA Model Documentation: Coal Market Module of the National Energy Modeling System}

This report documents the objectives and the conceptual and methodological approach used in the development of the National Energy Modeling System's (NEMS) Coal Market Module (CMM) used to develop the Annual Energy Outlook 1997 (AEO97). This report catalogues and describes the assumptions, methodology, estimation techniques, and source code of CMM's two submodules. These are the Coal Production Submodule (CPS) and the Coal Distribution Submodule (CDS). This document has three 
purposes. It is a reference document providing a description of CMM for model analysts and the public. It meets the legal requirement of the Energy Information Administration (EIA) to provide adequate documentation in support of its statistical and forecast reports (Public Law 93275, Federal Energy Administration Act of 1974, Section 57.b.1), as amended by Public Law 94385). Finally, it facilitates the continuity in model development by providing documentation from which energy analysts can undertake model enhancement, data updates, and parameter refinements as future goals to improve the quality of the module.

DOE/EIA-M060(97) One-Time Mar 1997 $159 \mathrm{pp}$.

\section{EIA Model Documentation: Natural Gas Transmission and Distribution Model of the National Energy Modeling System}

This report documents the archived version of the Natural Gas Transmission and Distribution Model (NGTDM) that was used to produce the natural gas forecasts used in support of the Annual Energy Outlook 1997, DOE/EIA-0383(97). The purpose of this report is to provide a reference document for model analysts, users, and the public that defines the objectives of the model, describes its basic design, provides detail on the methodology employed, and describes the model inputs, outputs, and key assumptions. It is intended to fulfill the legal obligation of the EIA to provide adequate documentation in support of its models (Public Law 94-385, Section 57.b.2). This report represents Volume I of a two-volume set. The version of the model used in support of the Annual Energy Outlook 1995, Volume II reported on model performance, detailing convergence criteria and properties, results of sensitivity testing, comparison of model outputs with the literature and/or other model results, and major unresolved issues. A second volume was not produced for the Annual Energy Outlook 1996 version.
DOE/EIA-M062/1(97) One-Time Mar 1997 $150 \mathrm{pp}$.

\section{EIA Model Documentation: Documentation of the Oil and Gas Supply Module (OGSM)}

The purpose of this report is to define the objectives of the Oil and Gas Supply Model (OGSM), to describe the model's basic approach, and to provide detail on how the model works. This report is intended as a reference document for model analysts, users, and the public. It is prepared in accordance with the Energy Information Administration's (EIA) legal obligation to provide adequate documentation in support of its statistical and forecast reports (Public Law 93-275, Section 57.b.2).

DOE/EIA-M063(97) One-Time Mar 1997 $247 \mathrm{pp}$.

\section{EIA Model Documentation: Industrial Sector Demand Module of the National Energy Modeling System}

This report documents the objectives, analytical approach, and development of the National Energy Modeling System (NEMS) Industrial Demand Model. The report catalogues and describes model assumptions, computational methodology, parameter estimation techniques, and model source code. This document serves three purposes. First, it is a reference document providing a detailed description of the NEMS Industrial Model for model analysts, users, and the public. Second, this report meets the legal requirement of the Energy Information Administration (EIA) to provide adequate documentation in support of its models (Public Law 94-385, Section 57.b.2). Third, it facilitates continuity in model development by providing documentation from which energy analysts can undertake model enhancements, data updates, and parameter refinements as future projects. 
DOE/EIA-M064(97) One-Time Mar 1997

$125 \mathrm{pp}$.

\section{Model Documentation Report: Industrial Sector Demand Module of the National Energy Modeling} System

This report documents the objectives, analytical approach, and development of the National Energy Modeling System (NEMS) Industrial Demand Model. The report catalogues and describes model assumptions, computational methodology, parameter estimation techniques, and model source code. This document serves three purposes. First, it is a reference document providing a detailed description of the NEMS Industrial Model for model analysts, users, and the public. Second, this report meets the legal requirement of the Energy Information Administration (EIA) to provide adequate documentation in support of its models (Public Law 94-385, Section 57.b.2). Third, it facilitates continuity in model development by providing documentation from which energy analysts can undertake model enhancements, data updates, and parameter refinements as future projects.

DOE/EIA-M064(98) One-Time Dec 1997 $114 \mathrm{pp}$.

\section{Model Documentation Report: Macroeconomic Activity Module (MAM) of the National Energy Modeling System}

This report documents the objectives, analytical approach, and development of the National Energy Modeling System (NEMS) Macroeconomic Activity Module (MAM) used to develop the Annual Energy Outlook for 1997 (AEO97). The report catalogues and describes the module assumptions, computations, methodology, parameter estimation techniques, and mainframe source code. This document serves three purposes. First, it is a reference document providing a detailed description of the NEMS MAM used for the $A E O 1997$ production runs for model analysts, users, and the public. Second, this report meets the legal requirement of the Energy Information Administration (EIA) to provide adequate documentation in support of its models (Public Law 94-385, Section 57.b.2). Third, it facilitates continuity in model development by providing documentation from which energy analysts can undertake model enhancements, data updates, and parameter refinements as future projects.

DOE/EIA-M065(97) One-Time Feb 1997 $100 \mathrm{pp}$.

\section{Model Documentation Report: Commercial Sector Demand Module of the National Energy Modeling System}

This report documents the objectives, analytical approach and development of the National Energy Modeling System (NEMS) Commercial Sector Demand Module. This report catalogues and describes the model assumptions, computational methodology, parameter estimation techniques, model source code, and forecast results generated through the synthesis and scenario development based on these components. This document serves three purposes. First, it is a reference document providing a detailed description for model analysts, users, and the public. Second, this report meets the legal requirement of the Energy Information Administration (EIA) to provide adequate documentation in support of its models (Public Law 93-275, Section 57.b.1). Third, it facilitates continuity in model development by providing documentation from which energy analysts can undertake model enhancements, data updates, and parameter refinements as future projects.

DOE/EIA-M066(97) One-Time Feb 1997 200 pp. 
Model Documentation Report: Residential Sector Demand Module of the National Energy Modeling System

This report documents the objectives, analytical approach, and development of the National Energy Modeling System (NEMS) Residential Sector Demand Module. The report catalogues and describes the model assumptions, computational methodology, parameter estimation techniques, and FORTRAN source code. This document serves three purposes. First, it is a reference document that provides a detailed description for energy analysts, other users, and the public. Second, this report meets the legal requirement of the Energy Information Administration (EIA) to provide adequate documentation in support of its statistical and forecast reports according to Public Law 93-275, Section 57.b.1. Third, it facilitates continuity in model development by providing documentation from which energy analysts can undertake model enhancements, data updates, and parameter refinements.

DOE/EIA-M067(97) One-Time Jan 1997 179 pp.

\section{Model Documentation Report: Residential Sector Demand Module of the National Energy Modeling System}

This is the fourth edition of the Model Documentation Report: Residential Sector Demand Module of the National Energy Modeling System (NEMS). It reflects changes made to the module over the past year for the Annual Energy Outlook 1998. Since last year, several new enduse services were added to the module including: Clothes washers, dishwashers, furnace fans, color televisions, and personal computers. Also, as with all NEMS modules, the forecast horizon has been extended to the year 2020. Two new columns were added to the detailed technology database. One column relates the water heating energy savings associated with the use of more efficient clothes washers and dishwashers and the other specifies the use of furnace fans with central space conditioning systems. This report documents the objectives, analytical approach, and development of the National Energy Modeling System (NEMS) Residential Sector Demand Module. The report catalogues and describes the model assumptions, computational methodology, parameter estimation techniques, and FORTRAN source code. This document serves three purposes. First, it is a reference document that provides a detailed description for energy analysts, other users, and the public. Second, this report meets the legal requirement of the Energy Information Administration (EIA) to provide adequate documentation in support of its statistical and forecast reports according to Public Law 93-275, Section 57.b.1. Third, it facilitates continuity in model development by providing documentation from which energy analysts can undertake model enhancements, data updates, and parameter refinements.

DOE/EIA-M067(98) One-Time Dec 1997 212 pp.

\section{EIA Model Documentation: Electricity Market Module Electricity Fuel Dispatch}

This report documents the National Energy Modeling System Electricity Fuel Dispatch Submodule (EFD), a submodule of the Electricity Market Module (EMM) as it was used for EIA's Annual Energy Outlook 1997. It replaces previous documentation dated March 1994 and subsequent yearly update revisions. This report catalogues and describes the model assumptions, computational methodology, parameter estimation techniques, model source code, and forecast results generated through the synthesis and scenario development based on these components. This document serves four purposes. First, it is a reference document providing a detailed description of the model for reviewers and potential users of the EFD including energy experts at the Energy Information Administration 
(EIA), other Federal agencies, state energy agencies, private firms such as utilities and consulting firms, and non-profit groups such as consumer and environmental groups. Second, this report meets the legal requirement of the Energy Information Administration (EIA) to provide adequate documentation in support of its statistical and forecast reports (Public Law 93275, Section 57.b.1). Third, it facilitates continuity in model development by providing documentation which details model enhancements that were undertaken for $A E O 97$ and since the previous documentation. Last, because the major use of the EFD is to develop forecasts, this documentation explains the calculation, major inputs and assumptions which were used to generate the $A E O 97$.

DOE/EIA-M068-D(97) One-Time Mar 1997 $97 \mathrm{pp}$.

\section{Model Documentation: Renewable Fuels Module of the National Energy Modeling System}

This report documents the objectives, analytical approach, and design of the National Energy Modeling System (NEMS) Renewable Fuels Module (RFM) as it relates to the production of the Annual Energy Outlook 1997 (AEO97) forecasts. The report catalogues and describes modeling assumptions, computational methodologies, data inputs, and parameter estimation techniques. A number of offline analyses used in lieu of RFM modeling components are also described. This document report serves three purposes. First, it is a reference document for model analysts, model users, and the public interested in the construction and application of the RFM. Second, it meets the legal requirement of the Energy Information Administration (EIA) to provide adequate documentation in support of its models (Public Law 93-275, Federal Energy Administration Act of 1974, Section 57.b.1). Finally, such documentation facilitates continuity in EIA model development by providing information sufficient to perform model enhancements and data updates as part of EIA's ongoing mission to provide analytical and forecasting information systems.

DOE/EIA-M069(97) One-Time Apr 1997 $166 \mathrm{pp}$.

\section{EIA Model Documentation: Transportation Sector Model of the National Energy Modeling System}

Over the past year, several modifications have been made to the NEMS Transportation Model, incorporating greater levels of detail and analyses in modules previously represented in the aggregate or under a profusion of simplifying assumptions. This document is intended to amend those sections of the Model Documentation Report (MDR) which describe these superseded modules. Significant changes have been implemented in the LDV Fuel Economy Model, the Alternative Fuel Vehicle Model, the LDV Fleet Module, and the Highway Freight Model. The relevant sections of the MDR have been extracted from the original document, amended, and are presented.

DOE/EIA-M070(97) One-Time Mar 1997 $108 \mathrm{pp}$.

\section{Forecasting}

\section{$65 \quad$ Annual Energy Outlook 1998}

The Annual Energy Outlook 1998 (AEO98) is the first $A E O$ with projections to 2020 . Key issues for the forecast extension are trends in energy efficiency improvements, the effects of increasing production and productivity improvements on energy prices, and the reduction in nuclear generating capacity. Projections in AEO98 also reflect a greater shift to electricity market restructuring. Restructuring is address through several changes that are assumed to occur in the industry, including a shorter capital recovery 
period for capacity expansions decisions and a revised financial structure that features a higher cost of capital as the result of higher competitive risk. Both assumptions tend to favor less capitalintensive generation technologies, such as natural gas, over coal or base load renewable technologies. The forecasts include specific restructuring plans in those regions that have announced plans. California, New York, and New England are assumed to begin competitive pricing in 1998. The provisions of the California legislation for stranded cost recovery and price caps are incorporated. In New York and New England, stranded cost recovery is assumed to be phased out by 2008 .

DOE/EIA-0383(98) Annual Dec 1997240 pp. GPO Stock Number: 061-003-01014-8 GPO Price: $\$ 23.00$

\section{International Energy Outlook 1997}

The International Energy Outlook 1997 (IEO97) presents an assessment by the Energy Information Administration (EIA) of the outlook for international energy markets through 2015. This report is an extension of the EIA's Annual Energy Outlook 1997 (AEO97), which was prepared using the National Energy Modeling System (NEMS). U.S. projections appearing in the IEO97 are consistent with those published in the AEO97. IEO97 is provided as a statistical service to energy managers and analysts, both in government and in the private sector. The projections are used by international agencies, Federal and State government, trade associations, and other planners and decisionmakers. They are published pursuant to the Department of Energy Organization Act of 1977 (Public Law 95-91, Section 205.c). The IEO97 projections are based on U.S. and foreign government policies in effect on October 1, 1996.

DOE/EIA-0484(97) Annual Apr 1997196 pp. GPO Stock Number: 061-003-00993-0

GPO Price: $\$ 13.00$

\section{Issues in Midterm Analysis and Forecasting 1997}

Issues in Midterm Analysis and Forecasting 1997 (Issues) presents a series of seven papers, which cover topics in analysis and modeling that underlie the Annual Energy Outlook 1997 (AEO97), as well as other significant issues in midterm energy markets. AEO97, DOE/EIA0383(97), published in December, presents national forecasts of energy production, demand, imports, and prices through the year 2015 for five cases -- a reference case and four additional cases that assume higher and lower economic growth and higher and lower world oil prices than in the reference case. The forecasts were generated using the Energy Information Administration's (EIA) National Energy Modeling System (NEMS). The papers included in Issues describe underlying analyses for the projections in $A E O 97$ and other analytical products of EIA's Office of Integrated Analysis and Forecasting. This provides public access to analytical work done in preparation for the midterm projections and to other unpublished analyses. Specific topics were chosen for their relevance to current energy issues or to highlight modeling activities in NEMS.

DOE/EIA-0607(97) Annual Jul 1997136 pp. GPO Stock Number: 061-003-00999-9

GPO Price: $\$ 11.00$

\section{Short-Term Energy Outlook Quarterly Projections}

The Short-Term Energy Outlook Quarterly Projections (STEO) presents quarterly forecasts of energy supply, demand, stock, and prices for each quarter. The forecasts are produced by using the Short-Term Integrated Forecasting System, which uses two principal driving variables; a macroeconomic forecast and world oil price assumptions. The three projections for petroleum supply and demand are based on low, middle, and high economic growth scenarios that incorporate high, middle and low crude oil price trajectories. The tables and discussion refer primarily to the middle, or base case scenario and to the domestic 
situation. Other cases which examine the sensitivity of total petroleum demand to varying assumptions about prices, weather and economic activity are presented. The petroleum outlook includes data projections of domestic crude oil production, motor gasoline, distillate fuel oil, residual fuel oil, and other products and inventories. Also included are natural gas, coal and electric power projections. Additionally, the international petroleum situation is discussed.

DOE/EIA-0202 Quarterly GPO Subscription Price: $\$ 17.00$ 


\section{Energy Information Administration's Products and Services}

\section{Electronic Publishing System (EPUB)}

EPUB is an electronic publishing system maintained by EIA. EPUB allows the general public to electronically access selected energy data from many of EIA's statistical reports. The system is a menu-driven, bulletin-board-type system with extensive online help capabilities that can be accessed free of charge 24 hours a day by use of a terminal or PC with an asynchronous modem. (EPUB will be taken down briefly at midnight, eastern time, for backup.)

PC users must provide the following information to their communications software in order to successfully access the EPUB system:

Communications Parameters:

Baud Rate: Up to 28,800 bps

Data Bits: 8; Stop Bits: 1

Parity: None; Duplex: Full

Terminal Type: ANSI, ANSI-BBS, VT100, etc.

Once communications software and/or hardware have been configured, EPUB can be accessed by dialing (202) 586-2557. When a connection to the system has been made, some users may find that the menu-driven instructions and the online capabilities will provide enough information to effectively use EPUB. More information may be obtained from:

National Energy Information Center, EI-30

Energy Information Administration

Forrestal Building, Room 1F-048

Washington, DC 20585

(202) 586-8800
Internet E-Mail: infoctr@eia.doe.gov

TTY: For people who are deaf or hard of hearing: (202) 586-1181

Hours: 9 a.m. to 5 p.m., M-F, eastern time

For communications or technical assistance, call (202) 586-8959, 8 a.m. to 5 p.m., eastern time, Monday through Friday. For questions about the contents of EPUB reports and data, call (202) 586-8800, 9 a.m. to 5 p.m., eastern time, Monday through Friday.

Following is a listing of some of the data and reports that are provided on EPUB:

\section{Coal, Nuclear, and Alternate Fuels}

Quarterly Coal Report (QSCR). Statistics on U.S. coal production, consumption, exports and imports, and stocks are provided by quarter for the most recent quarter and for previous years. Consumption and stocks are reported by end-use sector, and annual production trends are reported by State.

Updated 60 days after the end of the quarter.

\section{Oil and Gas}

\section{Heating Fuel Data (HFUL).}

Heating fuel data contain the most recent weekly/monthly data on production, imports, stocks, and residential and wholesale prices for residential heating fuels.

Updated every Thursday at 5 p.m., October through March, and the second week of the month April through September. 
Oxygenate Data (OXYDATA). Statistics by month on fuel ethanol, methyl tertiary butyl ether (MTBE), and methanol production, stocks, and amount blended into motor gasoline are reported. Data are by PAD District and for the total United States.

Updated approximately 15 working days after the end of the month.

Weekly Petroleum Status Report (WPSR). The latest U.S. petroleum balance sheet and the last five weeks of Weekly Petroleum Status Report data are reported. Data include domestic crude oil production, petroleum imports and exports, crude input to refineries, petroleum products supplied for consumption, and petroleum stocks.

Updated on Wednesdays (Thursdays in event of holidays) at 9 a.m., eastern time.

PSM State Stocks (STKS). The most recent month's data on refinery, bulk terminal, and natural gas plant stocks of selected petroleum products (product specific) by PAD District and State are reported.

Updated on the 20th of the month.

Petroleum Marketing Report (PMMR). Statistical data for the current three months and the reference month one year ago on crude oil and petroleum product prices and sales volumes are reported. Data are for the United States and by PAD District.

Updated on the 20th of the month.

Weekly On-Highway Diesel Prices (DIESLPRC). Weekly data by U.S. average and PAD District of the retail, on-highway, self service, cash price (including taxes) of diesel fuel are included. Prices are historical back to March 21, 1994.

Updated on Monday at 5:00 p.m, eastern time.
Weekly Retail Gasoline Prices (GASOLINE). Weekly data by U.S. average and PAD District of retail, unleaded regular, self service, cash price (including taxes) for motor gasoline are included. Updated on Tuesday at 5:00 p.m., eastern time.

Natural Gas Monthly (NGMR). Data for the most recent five months on natural gas supply and disposition and prices are reported. Data are at the national level for supply and disposition, consumption by consuming sector and price, and at the State level for end-use sector deliveries and price to end users.

Updated on the 20th of the month.

\section{EIA Press Releases}

The full text of the latest press releases from EIA is included.

Updated as new press releases are issued.

\section{Monthly Petroleum Imports}

Contains monthly data for the current reporting year and annualized data for the prior reporting years on crude oil and petroleum product imports into the United States. Data include the name of the importer of record, commodity imported, port of entry, quantity imported, percent sulfur by weight, API gravity, and processing company and location.

Updated monthly.

\section{Petroleum Supply Monthly}

Statistical data on the U.S. daily average supply and disposition of petroleum; crude oil production by State and PAD District; imports of petroleum into the United States by country of origin; and petroleum stocks by PAD District are reported. Data are primarily for the most recent month. Most of the tables reported in the Petroleum Supply Monthly are included.

Updated between the 23rd and 26th of the month. 


\section{Internet}

Inquiries can be sent to NEIC on the Internet. NEIC's E-Mail address is: infoctr@eia.doe.gov. The e-mail message should contain the following information: name, affiliation and address, daytime telephone number, fax number, and E-Mail address. NEIC will choose the best medium to respond to an inquiry as quickly as possible.

\section{EIA's World Wide Web Site}

EIA's World Wide Web site provides access to information on energy consumption, production, and prices; statistical and economic analyses; forecasts of short-term and midterm energy supply, demand, and prices; and other factors relating to the energy sector. There are fuelspecific databases that can be downloaded for use in spreadsheet and database programs. Voluminous data on supply, disposition, and prices of the major energy fuel/sources are presented in database format. Modeling applications that can be used to replicate the short-term and midterm forecasting EIA produces for the Short-Term Energy Outlook and the Annual Energy Outlook are also available for downloading. The World Wide Web address is:

\section{http://www.eia.doe.gov}

Internet users can also visit EIA's FTP server (ftp://ftp.eia.doe.gov) to access a variety of data files and reports.

Additional components of the site are:

- The most recent EIA press releases

- A section of most frequently asked general and most frequently asked technical questions

- A sign-up form for the EIA e-mail list subscriber service
The EIA Government Information Locator Service (GILS) records

- An energy events and EIA reports calendar

- An interactive query facility permitting users to generate customized output from EIA's data bases

Hypertext links to other useful energy information sites

\section{Electronic Mail List}

EIA's Internet electronic mail (e-mail) subscription service (commonly called a listserve) disperses electronic documents--weekly, monthly, quarterly, and occasionally--to an e-mail subscriber list. Documents include press releases, market reports, fuel watches, price data, and publication summaries.

\section{Energy InfoDisc}

EIA released its new CD-ROM, Energy InfoDisc, in February 1996. The Energy InfoDisc is EIA's latest electronic offering as the agency strives to increase the timeliness and usability of its information products. This compendium of EIA's national energy databases, publications, directories, and software applications brings EIA's comprehensive collection of energy information to users' fingertips.

Using CD-ROM technology, the Energy InfoDisc provides easy and inexpensive access to EIA's historical time series for production, consumption, prices, and resource availability of conventional and alternate energy resources; analyses of economic and technical topics; and projections of future energy supply, demand, and prices. 
The Energy InfoDisc allows the user to view and search more than 200 data, analysis, and forecasting reports and directories published over the previous 12 months. In addition, users can access EIA's extensive energy databases and specialized applications to generate their own individualized energy databases. Each issue highlights new products and any changes or enhancements to the CD. The Energy InfoDisc provides information about EIA's mission and goals as the primary source of statistical energy information to the public and provides a directory of EIA's energy experts by area of expertise. Contacts for other Federal statistical programs are also included.

The CD features the Monthly Energy Review; Short-Term, Annual, and International Energy Outlooks; Natural Gas: Issues and Trends; Electric Power and Renewable Energy Annuals among many other EA. reports and directories. The Energy InfoDisc also contains EIA's Monthly Energy Review Database; Oil and Gas Information Resource System (OGIRS) database; Direct Access Database (DADS) of coal, nuclear, and electricity data, and popular applications, including the Short-Term Model, the State Energy Data System, and World Energy Database.

EIA databases containing monthly and annual time series cover most aspects of energy supply and demand. Energy analysis applications allow users to examine selected aspects of EIA energy data, analyses, and forecasts and to display or tabulate the data in other ways for their own analysis.
Publications and directories are displayed in Portable Document Format (PDF); the Energy InfoDisc includes free Adobe Acrobat software for viewing and searching these documents. Most of the energy database applications are written in Microsoft Access. The Microsoft Access run-time engine required for these applications is also included.

The Energy InfoDisc is issued quarterly. The single issue price in the United States, Canada, and Mexico is $\$ 45$. Outside these areas, the price per issue is $\$ 60$. An annual subscription of four quarterly issues is $\$ 100$ in the United States, Canada, and Mexico and $\$ 160$ outside these areas. The Energy InfoDisc is distributed by STAT•USA, a U.S. Department of Commerce information service for business, economic, and trade professionals, through a cooperative agreement with EIA. To order, call 1-800STAT•USA, or (202) 482-1986. To find out more about the Energy InfoDisc and its contents, contact NEIC by phone: (202) $586-8800$ or by Internet E-Mail: infoctr@eia.doe.gov. 


\section{Subject Index}

(Numbers following entries refer to abstract numbers)

Alternative fuels $\mathbf{4 6}$

renewable fuels 48

Renewable Fuels Module 63

Coal

Coal Market Module 53

consumption $\mathbf{7 , 8}$

distribution 7,8

exports 8

financial statistics 29

imports 7,8

industry overview 7

prices 7,8

production 7,8

productivity 7

stocks 8

Coke

exports 8

imports 8

production 8

Commercial sector

Commercial Sector Demand Module 59

Crude oil

energy consumption 25,28

exports $17,18,19,22$

financial statistics 29

imports 17, 18, 19, 22

prices 16

production $17,18,19,22$

reserves 21

resources 15

stocks $17,18,19$

Oil \& Gas Supply Model 55

transportation 17, 18, 19

Degree-days 22, 25, 28

Directories

educational materials 6

energy information 2,3

publications 4,5

Educational materials 6

Electricity

competitive market environment 36

demand-side management 34, 44, 45

Electricity Market Module $\mathbf{6 2}$

environmental statistics 32, 33, 34 financial statistics $29,34,36,40,41,42$

fuel consumption 34,35

fuel costs 35

generating capability $34,35,43$

generation $34,35,43$

investment 37

power plant inventory 43

prices 34, 35, 36

privatization $\mathbf{3 7}$

reform 37

restructuring $32,33,36$

revenues $34,35,38,39$

sales $34,35,38,39$

Emissions

carbon mitigation 47

carbon stabilization 47

climate changes 47

greenhouse gases 26, 27, 46

Energy industry

financial statistics 29

manufacturing energy consumption $\mathbf{5 0}$

power plant inventory 43

Energy Information Administration

Ethanol

Annual Report to Congress 1

production 19, 22

production capacity 17,18

stocks 19, 22

Forecasts 65, 67, 68

international 66

nuclear power 23

Greenhouse gases 26, 27

Industrial sector $\mathbf{5 6 , 5 7}$

International statistics 11

forecasts $\mathbf{6 6}$

nuclear power 23

oil and gas resources 15

Manufacturing sector 50

Multi-Fuel 25, 28

consumption $\mathbf{3 0}$

price \& expenditure 31 
Models \& Modules

Coal Market Module 53

Commercial Sector Demand Module 59

Electricity Market Module 62

Industrial Sector Demand

Module 56, 57

Integrating Module 51

Macroeconomic Activity Module 58

Natural Gas Transmission \&

Distribution 54

Oil and Gas Supply Model 55

Petroleum Market Model 52

Renewable Fuels Module 63

Residential Sector Demand

Module 60, 61

Transportation Sector Model 64

MTBE

production 19, 22

production capacity 17

stocks 19,22

Natural gas

consumption 13, 14

exports 14

imports 14

prices 13, 14

production 13, 14

reserves 21

storage 14

Oil \& Gas Supply Model 55

Natural Gas Transmission \&

Distribution Model 54

Natural gas liquids

reserves 21

New Releases 4

Nuclear power

projections 23
Petroleum products 9, 10, 11, 12

consumption $9,10,17,18,19,22$

exports 17, 18, 19, 22

financial statistics 29

imports 17, 18, 19, 22

industry 20

international 11

issues \& trends 9, 20

market analysis 9, 12

Oil \& Gas Supply Model 55

Petroleum Market Model 52

pipelines 20

prices 16

production 17, 18, 19, 22

refinery operations 17

regulation 20

sales 10,16

stocks 17, 18, 19, 22

transmission 20

transportation 17, 18

Projections 65, 67, 68

international 66

nuclear power 23

Publications

directories 4, 5

Renewable Fuels 48

Renewable Fuels Module 63

Residential sector 49, 60, 61

State energy

consumption 30

price $\&$ expenditure 31

Transportation sector 64

alternative transportation fuels $\mathbf{4 7}$

household vehicles energy

consumption 32

Uranium

imports 24

industry 24

prices 24

production 24 


\section{How to Order from the National Energy Information Center}

Subscriptions and current in-stock single issues are available free of charge from NEIC for the following users: Government, news media, public and academic libraries, and EA.'s survey respondents.

Call (202) 586-8800 (or TTY: (202) 586-1181)) for more information or use the NEIC Order Form (see page 31). This form is also used for change of address, for deleting a name from the NEIC mailing list, or for ordering free publications.

\section{NOTICE}

Prices of EA. publications sold by the U.S. Government Printing Office (GPO) and the National Technical Information Service (NTIS) are subject to change without notice.

When EA. publications are discontinued and consolidated into other reports, the individuals who received copies of the terminated publication through the EA. mailing list are automatically placed on the mailing list for the new publication. Subscribers to discontinued, paid publications through GPO are generally sent refunds for any balance remaining on their subscription. For further information about paid subscriptions, please contact GPO at (202) 512-1800. 


\section{NEIC Orders}

\section{NATIONAL ENERGY INFORMATION CENTER ORDER FORM}

\section{TO ORDER FREE PUBLICATIONS--TO NOTIFY NEIC OF CHANGE OF ADDRESS --TO CANCEL A MAILING LIST PUBLICATION}

Mail to: National Energy Information Center, El-30 Energy Information Administration

Room 1F-048, Forrestal Building

Washington, DC 20585

Name

Business Affiliation

\section{Address}

City and State

Zip Code

1

Phone Number with area code
Mail List I.D. Number (found in upper left corner of your mailing label)

$\square \quad$ Change of address.

$\square \quad$ Add name to mailing list for free publication(s) as listed below.

$\square \quad$ Take name off mailing list for publication(s) as listed below.

$\square \quad$ Send the free publication(s) as listed below. 
M98005156

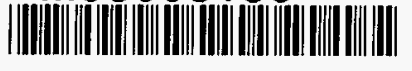

Report Number (14)DOE/EIA--0/49(97)

Publ. Date (11) $\frac{199804}{\text { DOE/EI, XF }}$
Sponsor Code (18)
UC Category (19) UC- 950, DOE/ER

no 1332,15 in follen

19980622049

DTIC QUALITY AVAPECTED I 
Mommy and Daddy Buy Me U.S. Savings Bonds for When I Go to College. 